\title{
YBL MIKLÓS ÉS A POLLACK CSALÁD ${ }^{1}$
}

\author{
KELECSÉNYI KRISTÓF ZOLTÁN \\ PhD-hallgató. BME Építészettörténeti és Müemléki Tanszék, \\ 1111 Budapest, Műegyetem rkp. 3. K. II. 82. Tel.: (+36-20) 969-2212. \\ E-mail: kristof.kelecsenyi@gmail.com
}

Ybl Miklós (1814-1891) még a 19. század első felében született építészeknek ahhoz a generációjához tartozott, akiknek az egyre bomló, de még fennálló céhes rendszerben és céhes hagyományok közepette kellett megszerezniük a tervezés és építés jogát. Pályája alakulásában így nagy szerep jutott Pollack Mihálynak (1773-1855), akinél inaséveit töltötte az 1830-as évek első felében, majd a magyar földön is tevékenykedő, bécsi Heinrich Kochnak (1781-1861). A fiatal Ybl, amíg nem vált a céh teljes jogú tagjává, az édesapja nyomán szintén építész, és mesterjoggal rendelkező Pollack Ágostonnal (1810-1872) társulva próbálkozott meg saját praxisának kiépítésével. A néhány évig tartó társulás legjelentősebb épülete az ikervári Batthyány-kastély. Ekkor kezdődött Ybl munkakapcsolata a Károlyi családdal. A fóti megbízások, majd azok nyomán az uradalmi építészi státusz biztosította a fiatal építész megélhetését, valamint az arisztokráciával való kapcsolatépítés lehetőségét. A Pollack Ágostonnal való társas viszonya legkésőbb 1850 körül megszünt. Pollack Mihály fiának tevékenységében a kis és közepes léptékü tervezési és építési feladatokról egyre inkább csak a kivitelezésre került át a hangsúly, majd Pollack Ágoston az 1860-as évek közepén teljesen felhagyott az építészettel. Ybl Miklós és a Pollack család kapcsolata azonban nem szakadt meg, a neoreneszánsz legnagyobb hazai mestere tervezte Pollack Mihály sírját, és árván maradt unokáját is örökbe fogadta.

Kulcsszavak: Pollack Mihály, Pollack Ágoston, Ybl Miklós, mester és tanítvány, klasszicizmus, romantika, historizmus

Az építészetben, mint bármilyen más alkotói tevékenységben, a mester és tanítványa közti viszony különös jelentőséggel bír egy építész pályájára nézve. Nem csupán a stílus, a szerkezeti és alaprajzi megoldások eltanulására és önkéntelen átvételére lehet itt gondolni, hanem egy olyan általános elvi és szigorúan gyakorlati gondolkodásmód elsajátítására, amelyből utóbb az önállósodásra képes utódok továbblépnek. Egy mester ezek mellett egy új vállalkozás elindításának is elősegítöje lehet. A kialakult építtetői körrel rendelkező, és gyakran igen sok, párhuzamosan futó tervezést és

\footnotetext{
${ }^{1}$ A tanulmány a XVI. Ybl Konferencia - Két Pollack és Ybl konferencián 2015. október 8-án elhangzott Pollack Mihály (1773-1855) mint Ybl Miklós mestere és Pollack Ágoston (1807/1810-1872/1882) mint Ybl cég- és munkatársa címü előadás szerkesztett és bővített változata. Elkészítésében tanácsaival, javaslataival, a szöveg fáradhatatlan gondozásával segítségemre volt doktori témavezetőm, Gyetvainé Balogh Ágnes. Közremüködését ezúton is köszönöm.
} 
építkezést felügyelő vezető építészek, építőmesterek a 19. századi gyakorlatban a kisebb vagy idő hiányában nem vállalt munkákra, maguk helyett legjobb tanítványaikat, munkatársaikat ajánlották. ${ }^{2}$ Az így kialakuló kapcsolatoknak utóbb újabb munkák, megbízások lehettek a következményei, ami önállósodásra bátorította a tanítványokat.

A mester és tanítvány viszony sokféle lehet. A 19. században legjellemzőbbek voltak ezek közül az apa és fia, a céhes mester és inasa, legénye, a tanár és diákja, vagy az építész és alkalmazottja között fennállók. Ezek a kapcsolati típusok időben akár követhették is egymást, ahogyan a mester és tanítvány viszonyból a fiatalabb alkotó partnerré emelkedett. Egy irodának természetesen egy - vagy ritkán, legfeljebb kettő - vezetője lehetett, így a mesterrel rokoni kapcsolatban nem álló, fiatal és ambiciózusabb építészek többnyire önállósodásra törekedtek, ahogyan történt ez Pollack Mihály és Ybl Miklós esetében is.

\section{YBL MINT POLLACK MIHÁLY TANÍTVÁNYA}

Ybl Miklós (1814-1891) pályája elindításában nagy szerepe volt Pollack Mihálynak (1773-1855). Ybl 1831-1832 telén beállt „Pollack Mihály kebelbeli építömester úrhoz inasképpen a nemes városi szabadalmaztatott kömíves czéhbe ${ }^{\prime} .{ }^{3}$ Erre, a 19. század elején még élő céhes gyakorlat szerint, a mesterjog elnyeréséhez volt szüksége. Ybl a bécsi Cs. Kir. Polytechnikum reáliskolájába 1826 tavaszán iratkozott be, ${ }^{4}$ majd 1828-tól 1831-ig a Polytechnikum Technikai Intézetének négy évfolyamát járta ki kitünő eredményekkel. ${ }^{5}$ Azt követően került Pollack mellé, hogy a budai székhelyü Országos Építészeti Igazgatóság elutasította felvételét. ${ }^{6}$ Ybl Ervin szerint Ybl Miklós édesapja még 1807-ben ismerkedhetett meg Pollackkal, aki éppen átdolgozta a fehérvári Vármegyeháza terveit. ${ }^{7}$ 1832-ben Ybl inasból legénnyé szabadult fel, és legkésőbb 1836. február 8-ig Pollack Mihály mellett müködött mint rajzoló. ${ }^{8}$

Ha megnézzük Pollack életmüvében az 1831 és 1836 közötti időszakot, az az érett müvek 1828-tól mintegy két évtizeden át tartó, Bibó István által meghatározott korszakába esik. ${ }^{9}$ Hogy ekkor az irodájában dolgozó Ybl rajzolóként milyen munkákban müködhetett itt közre, arról csak közvetett adatok vannak. E korszak elején fejezödött be a szekszárdi megyeháza (1827-1831) és az első pesti vigadó, a Redoute építése (1820-as évek-1832). Ybl Miklós 1882-ben keletkezett életrajzában is felbukkan az

\footnotetext{
${ }^{2}$ Ybl 1956a. 15; Bugár 2005. 189; Gerle 2010. 16, 19; Kelecsényi-Torma 2015. 93, 95, 100.

${ }^{3}$ Ybl 1956a. 8.

${ }^{4}$ Magyar Nemzeti Galéria Adattár (a továbbiakban MNG Adattár) 1670/1922 Ybl Miklós.

${ }^{5}$ Fleischer Gyula feljegyzése a bécsi Mủegyetem eredeti névkönyvéböl, 1939.12.14., MNG Adattár $6857 / 1954$.

${ }^{6}$ Neÿ 1879. 811.

${ }^{7}$ Ybl 1956a. 8.

${ }^{8}$ Ybl 1956a. 10-11.

${ }^{9}$ Bibó 2008. 113-160.
} 
a tény, hogy a fiatal építész két igen jelentős középület tervezésében és kivitelezésében is részt vett a Pollack-irodában: a Ludovikáéban és a Nemzeti Múzeuméban. ${ }^{10}$

1827 óta törvény szólt a Ludoviceum pesti helyszínen való felépítéséről, hogy a magyar katonai tisztképzés végre megindulhasson. ${ }^{11}$ Az 1830 nyarán történt alapköletételt követően az 1832. év végére már a tető is állt, azonban a berendezési munkálatok még folytak, többek közt a kápolnában. Pollack 1836-ban készítette el az építkezés zárójelentését. Az épületet azonban a kapcsolódó létesítmények - így a lovarda és az istálló - hiányára hivatkozva nem vették használatba. ${ }^{12}$ A Ludovika eredeti terv- és iratanyaga elveszett, így nem ismertek a közremüködők sem, az azonban biztos, hogy Pollack irodájában Ybl már pályája elején megismerkedett azzal, milyen szerteágazó feladatokkal jár egy nagyléptékű középítkezés.

Jelentőségében és méretében is felülmúlta a Ludovika munkáit a Pollack által irányított másik nagyszabású feladat, a Nemzeti Múzeum építése. ${ }^{13}$ József nádor ez esetben is Pollackot bízta meg a tervek elkészítésével és az építés vezetésével. Ismert, hogy Pollack már 1810-ben is készített vázlatokat a Nemzeti Múzeum céljára, de azok a tervek elvesztek. ${ }^{14}$ Mivel Ybl legkésőbb 1836 februárjában elhagyta a Pollackirodát, így legfeljebb csak a Nemzeti Múzeum előkészítésén dolgozhatott, annak részletes tervezésében és kivitelezésében nem vett részt, viszont Ybl 1882-es életrajzában felbukkan az az adat is, hogy Ybl müncheni tartózkodása idején küldött haza részletterveket a Múzeumhoz és a Német Színház átalakításához is. ${ }^{15}$

Pollack müveinek Zádor Anna és Bibó István által is közreadott jegyzéke alapján az 1832-1836 közötti időszakban kirajzolódik azon kevésbé jelentős épületek köre is, amelyeknek tervezéséből és esetleges kivitelezéséből a pályakezdő Ybl szintén

${ }^{10}$ Ybl Ervin önéletrajznak tartotta a Podmaniczky Frigyesnek, Ybl Miklós fél évszázados müködése alkalmából való kitüntetésére irányuló felterjesztéséhez mellékelt 1882-es életrajzot. Bár a dokumentum igen nagy részletességgel számol be Ybl Miklós iskoláiról, mestereiről, megvalósult épületeiről és terveiről, azonban nem ismerhető fel az építész kézírása, és az írást az előterjesztő Podmaniczky szignálta. Az adatok vélhetően magától Ybl Miklóstól származtak, azonban önéletrajznak az előbbiek miatt nem nevezhető. Magyar Nemzeti Levéltár (továbbiakban MNL OL), Miniszterelnökségi Iratok K 26 1844/1882. sz.: „,1836-ig Pollák Mihály pesti müépitész vezetése alatt az épitészet gyakorlati tanulmányozásával foglalkozott és a Ludoviceum épitésénél úgy szinte a Muzeum épitésének kezdeténél volt alkalmazva."

${ }^{11}$ Az épület számára 1829-ben vásárolták meg az Orczy család tulajdonában álló telket. (Horváth 1928. 44.) Pollack október végén ausztriai tapasztalatairól és a kialakult vázlattervről számolt be József nádornak, aki december 3-án neki ítélte a megbízást. (MNL OL Archivum Palatinale N22 1850/1892 sz. Közreadja: Bachó 1930. 124.)

${ }^{12} \mathrm{Az}$ eredetileg neki szánt funkcióját csak jóval később, Linzbauer István 1872-es neoreneszánsz ízü átépítését követően tölthette be, amely azonban számos jelentős belső teret - így a kápolnát és a főlépcsőházat lényegében érintetlenül hagyott. (Jász 2015. 54.)

${ }^{13} \mathrm{Az}$ intézményt 1802-ben alapította gróf Széchényi Ferenc, önálló épületet azonban csak évtizedekkel később kapott. 1836-ban a pozsonyi országgyülés által hozott törvény (1836. évi XXXVII. törvénycikk - a Nemzeti Múzeumról) rendelte el felépítését.

${ }^{14}$ Bibó 2008. 141.

${ }^{15}$ MNL OL, Miniszterelnökségi Iratok K 26 1844/1882. sz.: „, 1840-1842 Münchenben a királyi müvészeti akademiában tanulmányait végezte, és ugyanott azon időben Pollák Mihály épitész úr felszolitása folytán a pesti nemzeti muzeum nagy termének frescoral diszítéséhez és a pesti német szinház átalakitásához a terveket készitette." 
tanulhatott. ${ }^{16}$ A közel húsz, ma ismert munkából kiemelkedik Pollack barátjának, Dlauchy Ferencnek (1782-1859), a lakatos céh föcéhmesterének ${ }^{17}$ kétemeletes, a mai Király és Kazinczy utca sarkán álló bérháza $1833-b o ́ l,{ }^{18}$ valamint a szintén Dlauchy számára épített háromemeletes háza 1836-ból, ami a mai Kossuth Lajos és Városház utca sarkán állt egykor. ${ }^{19}$ Talán e munkákból és e kapcsolatból is következhetett három évtizeddel később az a megbízás, amelynek alapján Ybl megtervezte Dlauchy Ferenc fiának a mai Vámház körúton álló házát. ${ }^{20}$

Ybl következő mesterét, Heinrich Kochot ${ }^{21}$ (1781-1861), valamint későbbi rendszeres megbízóját, a Károlyi családot is Pollack Mihály révén ismerte meg. Gróf Károlyi György (1802-1877) megrendelésére és a bécsi székhelyü Koch tervei nyomán zajló pesti Károlyi-palota ${ }^{22}$ építkezésébe Pollack - irodájában a fiatal Ybllel Hofrichter József 1835-ös halálát követően, nem mint tervező, hanem mint kivitelező csatlakozott. ${ }^{23}$ A palota ünnepélyes felavatására 1841-ben került sor, amikor Ybl már Münchenben tartózkodott. ${ }^{24}$ Még az átépítés idején, 1840 májusában Pollack, Koch és Bártfay László (1797-1858), Károlyi György ügyvédje találkozott a pesti mester Városligeti fasori nyárilakjában. ${ }^{25} \mathrm{Az}$ a szakirodalomban elterjedt megállapítás, ${ }^{26}$ hogy Ybl később, egyedül Koch révén került kapcsolatba az utóbb állandó megbízójává váló Károlyi családdal, kétségbe vonható, e viszony létrejöttében korábbi mesterének, Pollack Mihálynak is éppen úgy szerepe volt.

Ybl Miklós legkésőbb 1836 elejéig elhagyta Pollack irodáját, mivel mestere ekkor, február 8-án állított ki ajánlólevelet a számára, mely dicsérte Ybl elméleti és gyakorlati tudását, szorgalmát és pontosságát. ${ }^{27}$ Ezzel szemben azonban egy 1891-ben, Ybl visszaemlékezése nyomán íródott cikkben az áll, hogy 1835 márciusáig dolgozott Pollack Mihálynál. ${ }^{28}$ Ybl rajzolóként ekkortól a Károlyi-palotát tervező és többször Pestre látogató Koch alkalmazásába lépett. Pollack és Ybl mester-tanítványi kapcsolata ekkor lezárult, az idősebb építész jó szívvel engedte tovább tanítványát, erről későbbi együttmüködésük és egymásról tett nyilatkozataik tanúskodnak.

\footnotetext{
${ }^{16}$ Zádor 1960. 411-423 és Bibó 2008. 173-178.

${ }^{17}$ Pereházy 1982. 231, 237.

${ }^{18}$ Zádor 1960. 420. Műemlék. Mai cím: VI. Király utca 21., Kazinczy utca 56.

${ }^{19}$ Zádor 1960. 421. Az épületet 1895 körül lebontották. Mai cím: V. Kossuth Lajos utca 2/b., Városház

${ }^{20}$ Tervei: Budapest Főváros Levéltára (a továbbiakban BFL) XV.17.f.331. - 043., mai cím: IX. Vámház

${ }^{21}$ Nem tévesztendő össze az ifjabb Heinrich Kochhal (1836-1889), Szkalnitzky Antal (1836-1878) építésztársával és sógorával. Sisa 1994. 32-33, 158. Sisa József nyomán megkülönböztetésükre az apánál a név német, a fiúnál annak magyar formáját használjuk.

${ }^{22}$ Mai címe: V. Károlyi utca 16., Ferenczy István utca 1., Henszlmann Imre utca 2.

${ }^{23}$ Bibó 2008. 138.

${ }^{24}$ Réh 1933. 102.

${ }^{25}$ Kalla Zsuzsa: Bártfay László naplói. Ráció Kiadó, Budapest 2010; Gábor 2010. 167, 441.

${ }^{26}$ Ybl 1956a. 15; Sisa 2014. 550.

${ }^{27}$ MNG Adattár 1684/1922 Ybl Miklós.

${ }^{28}$ Lehetséges, hogy az idős Ybl már nem emlékezett jól, de a hónapra pontosan megjelölt dátum és a személyes közlés ténye miatt ez a forrás is megemlítendő. (H. Gaál 1891. 3.)
} utca 2. körút 15. 


\section{YBL TEVÉKENYSÉGE HEINRICH KOCH MUNKATÁRSAKÉNT}

A bécsi székhelyű építész 1832-ben, más források szerint két évvel később vette át a szintén bécsi Anton Pius Rigeltől ${ }^{29}(1789-1868)$ a pesti Károlyi-palota átalakításának tervezői munkáit. ${ }^{30}$ Éble Gábor és Ybl Ervin tényként közölték, hogy Ybl ezen az épületen kezdett el dolgozni az osztrák építésznél, „valószínüleg” helyben, Pesten. ${ }^{31}$ Bibó István is rájuk támaszkodva állította, hogy az építész részt vett a munkákban, ugyanakkor az Ybl Ervin által megnevezett belső munkákról kimutatta, hogy azok nem lehetnek Ybl Miklós korai müvei. ${ }^{32}$ A palota kisebb átépítésének, bővítésének tervlapjai maradtak fenn az Ybl-hagyatékban. Ezek részben ismeretlen időpontban készültek, ${ }^{33}$ részben későbbről származnak, mert az 1837-ben született Károlyi Gyula volt a megrendelőjük. ${ }^{34}$ Mivel a Károlyi család a későbbiekben is sokat foglalkoztatta Yblt, a hagyatékban fennmaradt és az épülethez kapcsolódó tervek önmagukban nem igazolják Ybl ekkori szerepvállalását.

Ybl a Károlyi-palota átalakításáról előbb új munkaadója, Koch bécsi irodájába, majd rövidesen Prágába került. Itteni tevékenysége kapcsán több ellentmondás is felszínre került. Az 1882-ben keletkezett életrajz úgy fogalmaz, hogy Ybl „,Koch Henrik müépitész úr vezetése alatt mint önálló müvezetö a herczeg Kinsky Rezsö-féle palota kiépitését a prágai »Altstädter Ring " en keresztül vitte”. ${ }^{35}$ Ezzel szemben Ybl Ervin szerint ,fópallérként a prágai Smichowban özv. hg. Kinsky Rezsőnének (...) villa-palotája épitését" ${ }^{\prime 36}$ vezette. A problémát az jelenti, hogy a Kinsky családnak két rezidenciája is volt Prágában, és mindkettőn zajlottak ebben az időben építési-átépítési munkák. Az egyik épület az életrajzban is említett, a prágai Óvárosi fötéren álló barokk városi palota (Kilian Ignatz Dientzenhofer tervei nyomán Anselmo Lurago, 1755-1765) (1. kép), a másik pedig az Ybl Ervin által leírt Smíchov városrészben található villa. Azonban ez utóbbi, nyárilakként szolgáló épületet az osztrák és cseh szakirodalom szerint 1827-1831 és nem 1836-1839 között emelték, ${ }^{37}$ mint ahogyan azt Ybl Ervin írta. ${ }^{38} \mathrm{~A}$ barokk Kinksy-palotára ugyan ő is felhívta a figyel-

${ }^{29}$ Nevét a magyar szakirodalom Riegel formában használja, itt az osztrák írásmóddal szerepel.

${ }^{30}$ 1832-t ír Ybl Ervin (Ybl 1956a. 11), 1834-et Réh István (Réh 1933. 100) és Bibó István (Bibó 1984. 239).

${ }^{31}$ Éble 1897. 68 és Ybl 1956a. 9.

${ }^{32} \mathrm{Az}$ északi szárny emeleti folyosójának lezárt részéből kialakított házikápolna csak 1880 körül készült. (Bibó 1984. 243.)

${ }^{33}$ BFL XV.17.f.331.b - 18/1;2;3;5;6.

${ }^{34}$ BFL XV.17.f.331.b - 18/4;7;8. Köztük van egy kerti üvegház terve (8), az alábbi felirattal: „,Nagyméltóságú Gróf Károlyi Gyula úr Egyetem utcai Palotája kertjébe épitendö Virágház rajza”.

${ }^{35}$ MNL OL, Miniszterelnökségi Iratok K 26 1844/1882. sz.

${ }^{36} \mathrm{Ybl}$ 1956a. 9.

${ }^{37}$ Heinrich Koch. In: Architektenlexikon Wien 1770-1945; Architekturzentrum Wien, 2002-2013, hozzáférés: http://www.architektenlexikon.at/de/1141.htm (Utolsó megtekintés: 2016. 12. 13.); Radim Vondráček (szerk.): Biedermeier, umění a kultura v českých zemích 1814-1848. Uměleckoprůmyslové museum, Gallery, Prága 2008; Národní Památkový Ústav - Památkový Katalog; katalógussz.: 1000152407, hozzáférés: http:// pamatkovykatalog.cz (Utolsó megtekintés: 2016. 12. 13.)

${ }^{38}$ Ybl 1956a. 9. 


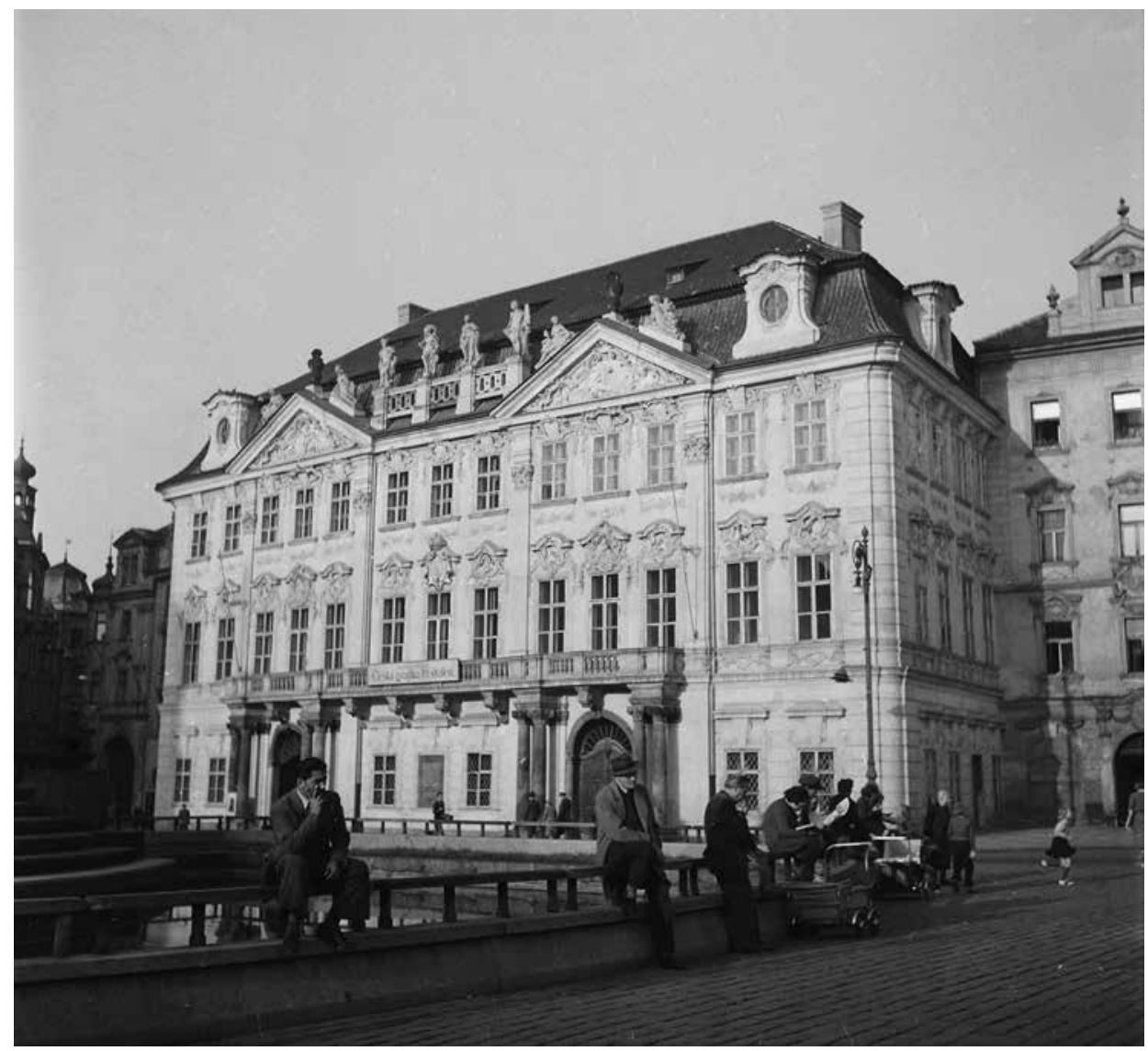

1. kép. A prágai Óvárosi főtéren álló Kinsky-palota. Forrás: Fortepan / Kotnyek Antal felvétele, 1959

met, azzal a kiegészítéssel azonban, hogy nem erről az épületről van szó. ${ }^{39}$ Pedig a városi palota Heinrich Koch- és a prágai német építész-építőmester Joseph Krannerféle (1801-1871) belső átépítését és bővítését pontosan Ybl prágai tartózkodásának idejére, 1836-1839 közé teszik, tehát bizonyosnak tünik, hogy Ybl inkább ezen az óvárosi épületen dolgozott. Újabb bizonytalanságot kelthet viszont az, hogy Kranner a smíchovi nyárilak belsőépítészeti kialakításában is közremüködött, melyre akár Ybl ottléte idején is sor kerülhetett.

Ugyanerre az időszakra esik a közép-csehországi Jarpice temetőjében álló klasszicista, latinkereszt alaprajzú Kinsky-temetkezőkápolna Koch-féle építése is 
(1836-1841). ${ }^{40}$ A Prágában zajlott, említett építkezések építőmestere, Kranner ${ }^{41}$ 1839. december 18-án állított ki bizonyítványt Ybl számára, melyben az építkezés során tanúsított szakértelméről, kötelességtudásáról nyilatkozott elismerően, és amelyet utóbb Prága város tanácsa is hitelesített. ${ }^{42} 1840$. február 8-án Heinrich Koch hasonlóan becses szavakkal teli igazolást adott a mindössze 26 éves Yblnek, mint amit négy évvel korábban Pollack Mihály. Dicsérte egyenes, nemes erkölcsét, amellett, hogy szakmai, elméleti és gyakorlati ismereteiről is pozitívan nyilatkozott. ${ }^{43}$

\section{YBL MÜNCHENBEN}

Pár nappal később, 1840. február 13-án Ybl már bizonyosan Münchenben tartózkodott, és 1882-es életrajza szerint 1842-ig az Akademie der Bildenden Künste óráit látogatta. ${ }^{44} \mathrm{Az}$ intézményben pont ebben az időben, 1841-ben történt igazgatóváltás. A nazarénus festő Peter von Corneliust (1783-1867) az ott 1820 óta professzorként múködő Friedrich von Gärtner (1792-1847) váltotta fel. ${ }^{45}$ Meglepő, de Ybl neve nem szerepel a beiratkozott hallgatók névsorában, nem úgy, mint az 1839 tavaszától szintén Münchenben tartózkodó és 1838-1839 folyamán szintén Pollack mellett dolgozó Feszl Józsefét6 (1819-1866) és ismertebb testvéréé Frigyesée ${ }^{47}$ (1821-1884), akik 1844 nyarán tértek csak vissza Pest-Budára. ${ }^{48}$

Ybl Ervin az Ybl Miklóst Münchenben érő hatásokat a korabeli bajor föváros építészeti újdonságaival támasztotta alá. ${ }^{49}$ Kiemelte ezek közül a Georg Friedrich Ziebland (1800-1873) által tervezett Szent Bonifác-templomot (1828-1850), amely a romanika elemeinek felelevenítésével újdonságként hatott München építészetében. Ybl Ervin szerint Ybl Miklós itt szerezte meg azokat az alapokat, amelyek korai alkotásaiban a romantika modorának megjelenéséért felelősek.

\footnotetext{
${ }^{40}$ Adatok forrása: Národní Památkový Ústav - Památkový Katalog; katalógussz.: 1000131464, hozzáférés: http://pamatkovykatalog.cz (Utolsó megtekintés: 2017. 01. 08.)

${ }^{41}$ Joseph Andreas Kranner (1801-1871) prágai születésű német építész, építőmester, a neogótikus stílus müvelője. Szülővárosában és Bécsben tevékenykedett. Részt vett a bécsi Votivkirche építésében, az 1860-as évek elejétől haláláig a prágai Szent Vitus-székegyház neogótikus kiépítésének Dombaumeistere.

${ }^{42}$ MNG Adattár 1685/1922 Ybl Miklós.

${ }^{43}$ MNG Adattár 1686/1922 Ybl Miklós.

${ }^{44}$ MNL OL, Miniszterelnökségi Iratok K 26 1844/1882. sz.

${ }^{45}$ Rektoren, Professoren, Ehrensenatoren und Ehrenmitglieder der Akademie der Bildenden Künste München 1808-2016, összeáll.: Brigit Jooss; Sabine Brantl 2016, hozzáférés: http://www.adbk.de/de/ akademie/archiv-historisches/professorenlisten.html (Utolsó megtekintés: 2017. 01. 07.)

${ }^{46}$ Matrikelbuch 1 (1809-1841), 2838. bejegyzés, iratkozás: 1839.05.31., hozzáférés: http://matrikel.adbk. de/matrikel/mb_1809-1841/jahr_1839/matrikel-02838 (Utolsó megtekintés: 2017. 01. 07.)

${ }^{47}$ Matrikelbuch 1 (1809-1841), 2839. bejegyzés, iratkozás: 1839.05.31., hozzáférés: http://matrikel.adbk. de/matrikel/mb_1809-1841/jahr_1839/matrikel-02839 (Utolsó megtekintés: 2017. 01. 07.)

${ }^{48}$ Komárik 1971. 398; Komárik 1993. 6-7.

${ }^{49}$ Leo von Klenze: Glyptothek (1830); Friedrich von Gärtner: Bayerische Staatsbibliothek (1827); Ludwigskirche (1829-1844). (Ybl 1956a. 12.)
} 


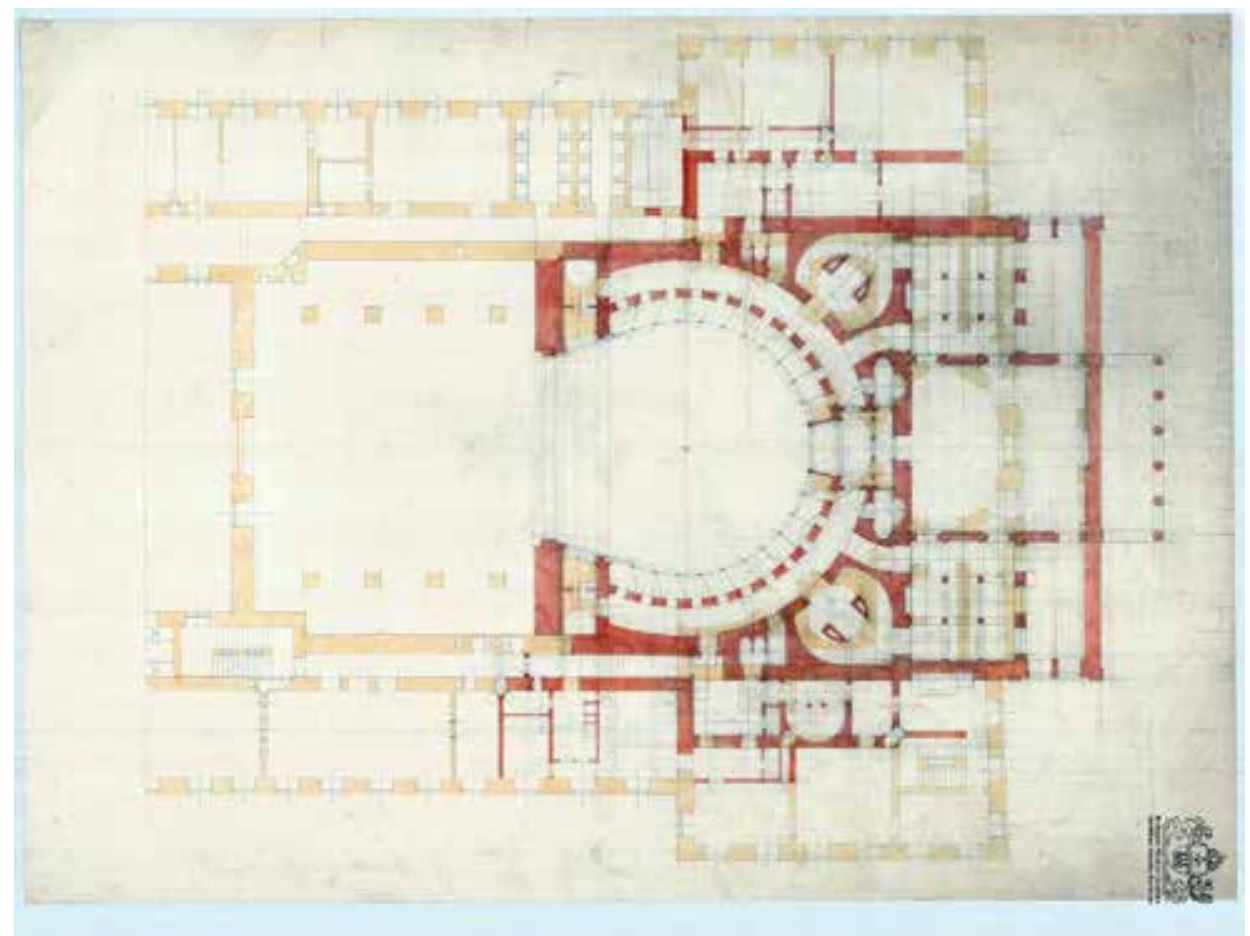

2. kép. A Német színház átépítésének terve. Ybl Miklós, 1840-41 körül.

Forrás: BFL XV.17.f.331.b 141/1

Ybl munkakapcsolata mind Pollackkal, mind Kochhal valamennyire ebben az időszakban is megmaradt. Az 1882-es életrajz szerint - ahogyan már említettük - Ybl még Münchenből küldött korai mesterének terveket a Magyar Nemzeti Múzeum dísztermének mennyezeti festéséhez és a pesti Német Színház átalakításához. Debreczeni-Droppán Béla szerint a Múzeumban ma is látható festésen érződik a müncheni nazarénus festők hatása, ,elsősorban az igazgató Peter Cornelius[é]” ${ }^{50} \mathrm{Ybl}$ Miklós hagyatékában található néhány rajz is, amelyek az 1807-1812 között Johann Aman (1765-1834) által tervezett és Pollack Mihály által kivitelezett ${ }^{51}$ Német Színház átalakítását mutatják. Ybl Ervin szerint ezek a rajzok az 1847-es tüzvészt megelőzően, az évtized elején készülhettek. ${ }^{52} \mathrm{Az}$ ovális előcsarnokot Ybl egy nagyobb, négyszögletes elötérrel kívánta helyettesíteni, valószínűleg a rendelkezésre álló tér jobb kihasználása végett (2. kép). Egy másik tervsorozaton a színházterem teljes átalakítása látható. Ybl Ervin szerint ezek alapján lehetséges, hogy ez utóbbi sorozat már a tüzvész után készült, hiszen csupa olyan alaprajzi változtatás látszik a

${ }^{50}$ Debreczeni 2014. 27.

${ }^{51}$ Zádor 1960. 122-127; Bibó 2008. 46-49.

${ }^{52}$ Ybl 1956a. 12-13. 
terveken, ami tüzbiztosabb megoldást eredményez. Legfeltünőbb ilyen elem a színpadi nyílás kisebbítése, de a tágasabb lépcsőházak is erre utalhatnak. ${ }^{53} \mathrm{~A}$ tervek datálását azonban bizonytalannak kell tekintenünk.

\section{YBL FELVÉTELE A PESTI CÉHBE}

Ybl 1841 tavaszának és nyarának jelentős részét Itáliában töltötte, amikor az északi országrész legfontosabb müvészeti központjait látogatta meg, de a leghosszabban, tizenkilenc napig Firenzében tartózkodott. Visszatérve Magyarországra 1841. augusztus 23-án benyújtotta a pesti tanácshoz felvételi kérelmét a „Helybeli Polgári Szabadalmas Építő Czéh" tagjai közé. ${ }^{54}$ Életrajza szerint 1842-ben még Münchenbe is visszatérhetett. A céh 16 hónappal a felvételi kérelem beadása után, 1842. december 27-én hozta meg az elutasító határozatot. ${ }^{55}$ Formai hibát az érvényes céhszabályok alapján nem találtak, de az indoklásban a Pesten megcsappant építőkedvre és a már így is túl sok itt tevékenykedő mesterre hivatkoztak. A döntést azonban Pest tanácsa méltánytalannak tartotta, és 1843 januárjában Ybl mégis „felvétetik” a mesterjelöltek közé. ${ }^{66} \mathrm{Ybl}$ ezt követően még ebben az évben sikeresen letette a kötelező elméleti vizsgát, azonban a szintén kötelező remeket nem készítette el, bár 1851-től a város és céh is sürgette. ${ }^{57}$ Yblt csak az egész birodalomban bevezetett új iparrendtartás alapján vették fel a mesterek közé 1863-ban, mivel ekkortól már nem volt kötelező a remeklés. Komárik Dénes szerint egyáltalán nem arról volt szó, mint amit Ybl Ervin ${ }^{58}$ sugall, hogy a céh ,,[b]izonyára a haladóbb, képzettebb, szélesebb látókörü szellem érvényesülését" akarta volna gátolni, hanem sokkal inkább arról, hogy Ybl egyszerüen nem törekedett a mesterjog megszerzésére. ${ }^{59}$ Ezt támasztja alá az is, hogy mind Pollack Mihály, mind fia, Ágoston igen jelentős szerepet töltött be a céhben, és e két évtized alatt, ha ezt a problémát kezelni akarták volna, bizonyára lett volna rá lehetőségük.

\section{YBL ÉS POLLACK ÁGOSTON TÁRSULÁSA}

1841 őszén - még a céh válaszára várva - Ybl társult a nála 4 évvel idősebb, apja befolyása révén már mesterjoggal rendelkező Pollack Ágostonnal (1810-1872). Az 1810. június 9-én ${ }^{60}$ Pesten született építészről keveset tudunk, neve leginkább Ybl

\footnotetext{
${ }^{53}$ BFL XV.17.f.331.b - 149/1;6;7;8;9;10;11;12 (ovális előcsarnokos terv); 149/2;3;4;5 (teljes átalakítás).

${ }^{54}$ MNG Adattár 1689/1922 Ybl Miklós.

${ }^{55}$ Nem számít kirívóan sok időnek a kortárs példák figyelembevételével (Komárik 1971 alapján).

${ }^{56} \mathrm{Ybl} 1956 \mathrm{a} .119$.

${ }^{57}$ Komárik 1971. 416.

${ }^{58}$ Ybl 1956a. 12, 118-119.

${ }^{59}$ Komárik 1971. 384.

${ }^{60} \mathrm{~A}$ szakirodalomban előfordul az 1807-es dátum is (Zádor-Rados 1943. 89), azonban Komárik az anyakönyvekre hivatkozik.
} 
Miklóssal kapcsolatban tünik fel. ${ }^{11}$ Pollack Mihály gyermekei közül ő volt az egyetlen, aki követte apját az építész pályán. Pollack Ágoston Pesten vélhetően a piaristák gimnáziumába járt, majd a bécsi képzőmüvészeti akadémiát látogatta 1828-1831 között, ${ }^{62}$ vagyis Ybllel egy időben tartózkodott a császárvárosban. 1829-ben az akadémia Gundel-díját is megkapta. A családi hagyomány szerint ${ }^{63}$ apja mellett, valamint Berlinben és Milánóban tanulta ki a szakmát, itáliai utazására 1830 nyarán kerülhetett sor. Pollack Mihály családi kapcsolatai indokolhatták a milánói tanulmányokat, ám édesapjával ellentétben Ágostonnak már nem volt módja az Itáliában hírnevet szerzett nagybácsitól, Leopoldo Pollacktól (1751-1806) tanulni a szakmát. ${ }^{64}$ Berlini útja során Schinkel (1781-1841) és köre hathatott a fiatal Ágostonra. Külföldi tanulmányait követően ismét apjánál dolgozott, aki Zádor Anna szerint igyekezett „megbízásainak jórészét fiára áthárítani," ${ }^{65}$ ami a gyakorlatban az apa irodájába beérkező magánmegbízások vezetését jelentette.

1833 májusi kérelmét követően, a következő év tavaszán jegyezték be Pollack Ágostont önállóan a pestvidéki építőmesterek közé. ${ }^{66}$ Mesterfelvételi iratai nem maradtak fenn, ebböl Komárik Dénes arra következtetett, hogy ügye „simán és gyorsan zajlott (...) le", ${ }^{67}$ ami édesapja tekintélyét és céhben betöltött szerepét tekintve valóban elképzelhető. ${ }^{68} \mathrm{Nem}$ teljesen világos ugyanakkor, hogy Ágoston miért pestvidéki mesterként került a céh soraiba, hiszen apja révén ő is a városban számíthatott megbízásokra, amit a gyakorlat igazolt is. ${ }^{69}$ 1834-től 1847-ig 151 építési engedélyt adtak ki a neve alatt futó tervekre, bár 1835-1836 során egyetlenegy tervet sem nyújtott be ${ }^{70}$ (1. táblázat). Munkái közül a legjelentősebb a Rókus Kórház volt. 1838 után a Pest város tanácsától kapott engedély szerint az addig az épület bővítésén dolgozó apjától Ágoston vette át a kórház átépítésének tervezését és kivitelezését, ami 1840-ben zárult le. ${ }^{71}$

\footnotetext{
${ }^{61}$ Részletesebben tárgyalják: Lyka 1933. 56-57; Zádor-Rados 1943. 89-91; Komárik 1971. 409.

${ }^{62}$ Fleischer 1935. 76; Zádor Anna kételkedett a Pollack Ignác Ágoston néven az akadémia nyilvántartásába került személynek és Pollack Mihály fiának azonosságában, szerinte „,aligha azonos (...) bár az időpont nem mondana ellen az azonosításnak" (Zádor-Rados 1943. 255); Komárik Dénes viszont elfogadta az azonosítást. A gimnáziumra vonatkozó adat is tőle származik. (Komárik 1971. 409.)

${ }^{63}$ Lyka Károly Palliardi Ágostonné Pollack Ellára, az építész unokájára hivatkozik, mint adatközlöre. (Lyka 1933. 56.)

${ }^{64}$ Összefoglalja Zádor 1931.

${ }^{65}$ Schneider 1912. 213; Zádor-Rados 1943. 90.

${ }^{66}$ Komárik 1971. 409. Bierbauer a pestvidéki mestereket összegző táblázatában közli nevét, ez alapján lehetséges, hogy egy ideig vidéki mesterként volt bejegyezve. (Bierbauer 1932.)

${ }^{67}$ Komárik 1971. 389.

${ }^{68}$ Pollack Mihály 1812-ben Kaszellik Fidéllel és Zitterbarth Jánossal együtt jelölt volt a céh főcéhmesterének választásán (Schneider 1912. 212), Zádor Annánál nem találunk erre utaló említést, de Bibó István szerint Pollack a céh fő elöljárója is lett. (Bibó 2008. 13, 57.) 1838-ban már a céh köztiszteletben álló, rangidős mestere volt. (Schneider 1912. 213.) A céhek általában könnyebben utat engedtek a felvételnél a céhtagok rokonainak. (Balogh 1998. 115.)

${ }^{69}$ Úgynevezett vidéki mesternek azok számítottak, akik nem Pesten vagy Budán éltek és müködtek, de bejegyeztették magukat a pesti vagy budai fócéhbe, és adót is fizettek számára. (Duray 1914. 133-134.)

${ }^{70}$ Bierbauer 1932. 83.

${ }^{71}$ Schoen 1938. 11; Schoen 1939. 18; Zádor-Rados 1943. 255.
} 


\begin{tabular}{|c|c|c|c|c|c|c|c|c|c|}
\hline 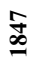 & $\stackrel{0}{ }$ & $\sim$ & 0 & $r$ & $\cong$ & $\stackrel{\infty}{\infty}$ & $r$ & 1 & ก \\
\hline$\underset{0}{0}$ & $\simeq$ & in & 0 & $\infty$ & $\stackrel{\infty}{\sim}$ & $\stackrel{\infty}{\sim}$ & $\nabla$ & $a$ & $\stackrel{8}{8}$ \\
\hline$\underset{\substack{0 \\
0}}{0}$ & $\infty$ & - & 0 & 0 & $=$ & $m$ & $a$ & $\sim$ & t \\
\hline 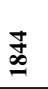 & $m$ & $m$ & 0 & $r$ & 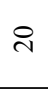 & $\stackrel{\sim}{\sim}$ & 0 & $n$ & in \\
\hline$\stackrel{\mathscr{f}}{\infty}$ & $r$ & $N$ & in & 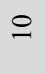 & ల & $\simeq$ & $\nabla$ & $m$ & 8 \\
\hline$\underset{\infty}{ \pm}$ & $\nabla$ & 0 & $\nabla$ & $\varrho$ & m & $\stackrel{\infty}{\sim}$ & $\infty$ & $\sim$ & 8) \\
\hline$\underset{\Phi}{ \pm}$ & 6 & $N$ & $N$ & $\cong$ & $\stackrel{\sim}{\sim}$ & ભ & $\cong$ & $a$ & $\bar{a}$ \\
\hline$\underset{\&}{\stackrel{P}{\infty}}$ & 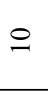 & $N$ & $\nabla$ & $\hat{\imath}$ & in & $\tilde{m}$ & $=$ & $\ddot{\sim}$ & $\stackrel{\mathscr{I}}{\simeq}$ \\
\hline$\stackrel{\infty}{\infty}$ & $\stackrel{\sim}{n}$ & ते & $n$ & $\bar{m}$ & $\underset{m}{\infty}$ & $\therefore$ & $\mathscr{F}$ & $\bar{\infty}$ & હ్లి \\
\hline$\stackrel{\infty}{\infty}$ & in & $\stackrel{2}{ }$ & $\stackrel{0}{0}$ & 1 & gे & $\tilde{n}$ & $\dot{m}$ & $\tilde{6}$ & क्సे \\
\hline$\stackrel{\tilde{\infty}}{=}$ & $\sim$ & 은 & $\sim$ & 1 & 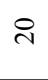 & $\cong$ & $\stackrel{0}{ }$ & $\stackrel{0}{ }$ & $\hat{6}$ \\
\hline$\stackrel{\infty}{\infty}$ & 0 & $N$ & $=$ & 1 & $\infty$ & $\simeq$ & $\infty$ & $a$ & 8 \\
\hline$\stackrel{\infty}{\infty}$ & 0 & $m$ & - & 1 & $n$ & $\sim$ & in & $\simeq$ & $\stackrel{\sim}{\sim}$ \\
\hline$\stackrel{\Xi}{\infty}$ & - & 0 & $m$ & 1 & $\simeq$ & $a$ & 0 & $\stackrel{\infty}{\sim}$ & Fे \\
\hline$\stackrel{50}{\stackrel{0}{\circ}}$ & $\vec{a}$ & $\dot{n}$ & $\dot{2}$ & हे & $\dot{\mathbf{n}}$ & $\dot{\mathbf{Q}}$ & $\dot{\varrho}$ & $\dot{2}$ & 1 \\
\hline 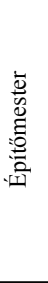 & 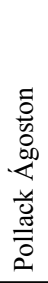 & 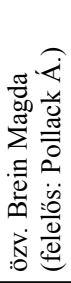 & 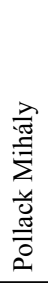 & 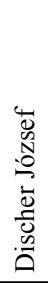 & 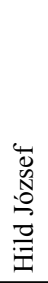 & 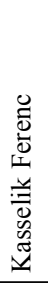 & 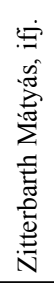 & 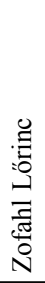 & 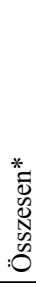 \\
\hline
\end{tabular}


1839-ben kerültek a Szépítő Bizottmány elé az Üllői úti Josephinum fiúárvaházának tervei, melynek szerzősége a Pollack-kutatás számára is kérdéses maradt, bár a kutatók inkább az idősebb mester életmüvének részeként tárgyalták. ${ }^{72} \mathrm{Az}$ apa szerzőségének mond ellent, hogy az épület a klasszicizmustól eltérően, a romantika és a korai neoreneszánsz jegyeit mutatta, ráadásul engedélyezési terveit sem Pollack Mihály, hanem a fia, Ágoston írta alá. ${ }^{73}$ Zádor Anna szerint - aki nem ismerte még az apa 1970-ig lappangó, 1840-es, neoreneszánsz stílusú Országháza tervét ${ }^{74}$ - a tervezést Pollack átengedte fiának és a vele együtt dolgozó Ybl Miklósnak, ezért ő nem tekintette Pollack Mihály müvének. Az Országháza terveket felfedező Bibó István viszont a szignó kérdését nem tekintette döntőnek, hiszen szerinte az a kivitelező személyével állt elsősorban összefüggésben. Sokkal fontosabbnak tartotta a törvényhozás épületére készült tervekkel való párhuzamokat, és ez alapján a Josephinumot az apa munkásságához sorolta. A szerzőség kérdése tehát nem dönthető el, de annyi biztosan megállapítható, hogy az 1841-1843 között csak részben megvalósult tervek kiviteléért Pollack Ágoston volt a felelős.

\section{AZ ÉPÍTÉSZETI INTÉZET HIRDETÉSEI}

Az Ybl Miklós és Pollack Ágoston társulásával létrejött - általuk Építészeti Intézetnek nevezett -, közös iroda 1841. október 30-ától kezdte hirdetni magát. Az építészpáros a néhai Vogel Sebestyén (1779-1837) pesti belvárosi Dorottya utcai ${ }^{75}$ házának második emeletén rendezte be irodáját. Az épületet 1824-ben Pollack Mihály tervezte és építette a gyakran vele dolgozó asztalos bútorgyárosnak. Az 1838-as pesti árvíz után felfutó építkezésszám épp az 1840-es évek elején esett vissza az engedélyezések számából ítélve (1. táblázat). Az 1838-39-es időszak volumenét jóllehet akkor kisebb munkák tömegéről lehetett szó - Hild József (1789-1867) és részlegesen Kasselik Ferenc (1795-1884) tudta még ekkor is fenntartani.

A Pollack-Ybl építészpáros 1841-1842 telén a napilapokban, így a Pesti Hírlapban ${ }^{76}$ és a Világ címü lapban ${ }^{77}$ adott közre hirdetéseket:

„, Alábbirottak egész tisztelettel jelentjük; hogy mi Magyarország és a'hoz tartozó melléktartomány'ok számára, a'szerint, valamint Bécs, Páris, London és több fövárosokban tapasztaltatik, épitészeti terveinket és utasitásainkat, a't. cz. közönség nagyobb kéjelmére alázatossággal ajánlani kívántuk: miszerint mindennemü köz és magányos épületi terveket, polgári és megyei házakat, kertalkatokat, gazdasági épü-

\footnotetext{
${ }^{72}$ Zádor 1960. 297-300; Bibó 2008. 158-159.

${ }^{73}$ BFL XV.17.b.331 SzB 8728.

${ }^{74}$ Bibó 1973.

${ }^{75}$ Korabeli számozás szerint 16. szám, az utca 19. század közepi átszámozását követően 5. szám. Az épület telkét további két oldalról közterületek határolták, a Wurm (ma Szende Pál) utca és a József (ma József nádor)

${ }^{76}$ Pesti Hírlap 1841. (1. évf.) október 30. (87. sz.) 736.

${ }^{77}$ Világ 1841. október 30, 372.
} tér. 
leteket, és ünnepi diszitményeket, valamint az úri 's polgári lakásokban, a’ belsö elintézéseket illetö rajzokat elkészitendjük, és azokat minden épitési-müvész vagy kézmüvesek meghagyásából is felvállalván, az épitéshez való, mindennemü ügyröl rendes utasitást adandunk.

A'megnevezett épitési tárgyakról elkészitendö, tervek és javaslatok, az előadandó készitmények elöleges, a’ helybeli körülményekhez mért költségkivetéseikkel együtt kidolgozva, mérsékelt tiszteletdij mellett, a’ megbizónak egész készséggel kézhez fognak szolgáltatni, az építési végrehajtást, vagy felelet teher alatt, vagy a' nélkül is felvállalván, vagy csak az épitési felügyelést is átveendjük.

Német, Franczia, Angol, és Olaszországokban volt hosszabb tartózkodásunk alatt, az építési-osztályban szerzett jártasság és tapasztalás, nemkülönben az általunk elkészitett nagyobb épületek kivitelével is, a' technicai és aestheticai tudományban tett ismeretekkel a' jelenkor kivánatihoz képest kimüvelve, minden épitési megbizásnak, valamint a' kül csinosság —úgy az építészi gazdálkodásra és annak czélirányos végrehajtására nézve, megfelelni képesek vagyunk.

\section{Pollack Ákos ${ }^{78}$ épitömester} és Ybl Miklós építész."

Hirdetéseik 1841 október-novemberében, valamint 1842 februárjában összesen öt alkalommal jelentek meg az éppen elindított Pesti Hirlap hasábjain, közülük az első kettő a fentebb idézett szöveggel jelent meg, ${ }^{79}$ majd november 11-én „Építészeti ajánlkozás" címmel a Pozsonyi Hírnök is közölte. ${ }^{80}$ Az első hirdetés szöveges tartalmát rövid hírként is megismételte 1841 decemberében a Pesti Hirlap ${ }^{81}$ A következő év februárjában a már háromszor megjelent szöveg nem változott, csak a címe „Építészeti intézet” lett. ${ }^{82}$ Az újságokban Ágoston nevét következetesen a talán magyarosabban csengő Ákosként adták meg. Nemcsak a hirdetések feladása jelentett újdonságot, de az is, hogy addig kizárólag asztalosmunkának számító belsőépítészeti tervezést is vállaltak. ${ }^{83}$

\section{YBL ÉS POLLACK ÁGOSTON KÖZÖS MUNKÁI}

Ha pozsonyi munkáról nincs is forrásunk, de Debrecenbe eljutott a társulás híre - még ha nem is hirdetés útján. A református Nagytemplom tetőszerkezete az 1830as évekre igen rossz állapotba került, ám akkor az ügy elodázódott. ${ }^{84} 1841$ áprilisában érkezett meg Pestre a debreceniek kérése, hogy Hild József (1789-1867) vagy

\footnotetext{
${ }^{78}$ Nevének ezzel a formájával az ugyanebben az időszakban keletkezett debreceni forrásokban és az ezek alapján készült müvekben is találkozunk (pl. Balogh 1958).

${ }^{79}$ Pesti Hirlap 1841. (1. évf.) november 13. (91. sz.) 770.

${ }^{80}$ Hirnök 1841. (5. évf.) november 11. (91. sz.) [4].

${ }^{81}$ Pesti Hírlap 1841. (1. évf.) december 8. (98. sz.) 822.

${ }^{82}$ Pesti Hirlap 1842. (2. évf.) február 3. (114. sz.) 84., február 10. (116. sz.) 100., február 20. (120. sz.) 126.

${ }^{83}$ Sisa 2013. 311.

${ }^{84}$ Kun 1930. 22-23.
} 
Pollack Mihály az egyház költségén utazzon le megvizsgálni a Nagytemplom fedélszékét. Hild bár ígérkezett, végül nem jutott el Debrecenbe. Pollack pedig maga helyett a fiát küldte, aki november 25-én érkezett meg a városba. 1842 júniusára Pollack Ágoston és Ybl három alternatívát is kidolgoztak, melyek közül az egyik a templomot a Péchy Mihály (1755-1819) által is elképzelthez hasonlóan, kupolával koronázta volna meg, egy másik megoldás attikafalat emelt volna a tető elé, ezzel megoldva a falak és a szerkezet csatlakozását, a harmadik pedig az első megoldás müszaki részleteit tartalmazta, de a kupola nélkül. A Consistorium szakvéleményezés céljából egy névtelenül maradó pesti építésznek is megmutatta a terveket, aki a kupolát kritizálta. A tervek negatív visszhangja Ybl Ervin szerint nem volt független Ybl és a céh - általa hüvösnek tartott - viszonyától. ${ }^{85}$ „A tervezett kúp koronája leend az egész münek és nemcsak magának a templomnak, de az egész városnak dísze leendvén a fénypontja, nagyszerüsége által minden szemet megörvendeztet" - írták a fiatal tervezők az erre adott reakciójukban. Végül Povolny Ferenc (1777-1847) építőmester bevonásával, de a kupola nélküli Pollack-Ybl-féle fedélszékterv változtatás nélküli felhasználásával készült el a munka $1844-1845$ folyamán. ${ }^{86}$

Debrecenből további két, nagyobb igényü, de meg nem valósult munkájuk is ismert, melyek megbízója a református egyház volt. Az 1803-1816 között épült kollégium mögött részben fennmaradt, régebbi oktatási épület már annyira romos volt ekkor, hogy nem tudták használni. ${ }^{87}$ Vélhetően a Nagytemplom miatt tett látogatása idején Pollack Ágoston ezt az épületegyüttest is megszemlélte, és nem javasolta fenntartását, viszont terveket készített az oratórium mennyezetéhez, melyek kivitelre is kerültek. ${ }^{88} 1842$ januárjában Ybl és Pollack felmérették a rossz állapotú debreceni református Kistemplomot. ${ }^{89}$ A következő évben készítették el az átépítési terveket, ${ }^{90}$ melyek két alternatívát vázoltak fel a megrendelő előtt, de utóbb anyagi okokból elvetették őket (3. kép). Az egyik terv jelentősebb átépítéssel, kevesebb fennálló fal meghagyásával, ${ }^{91}$ a másik a falak bővítés nélküli megújításával számolt. ${ }^{92}$ Mindkét terv a romantika szellemében fogant, a nagyobb beavatkozást jelentő a müncheni Ludwigskirche (1829-1844) Rundbogenstiljével rokon, míg a másik stíluskapcsolatai Firenze késő gótikus és kora reneszánsz templomépítészetében kereshetők. A fennmaradt tervlapokon jól megfigyelhető Pollack Ágoston és Ybl jellegzetes, közös aláírása, mely egy „P”-böl és egy alatta elhelyezkedő „Y”-ból áll (4. kép). E szignó számos, később keletkezett tervlapon is felfedezhető az Ybl-hagyatékban, e munkák bizonyítják a leghitelesebben közös müködésük eredményeit.

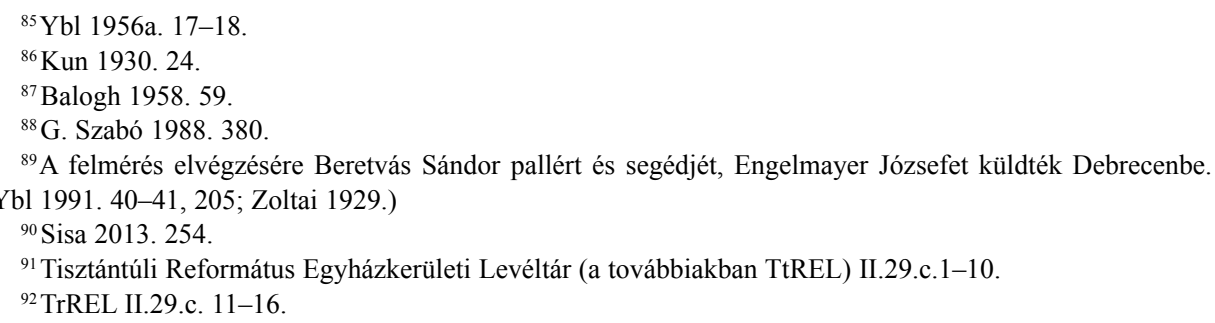



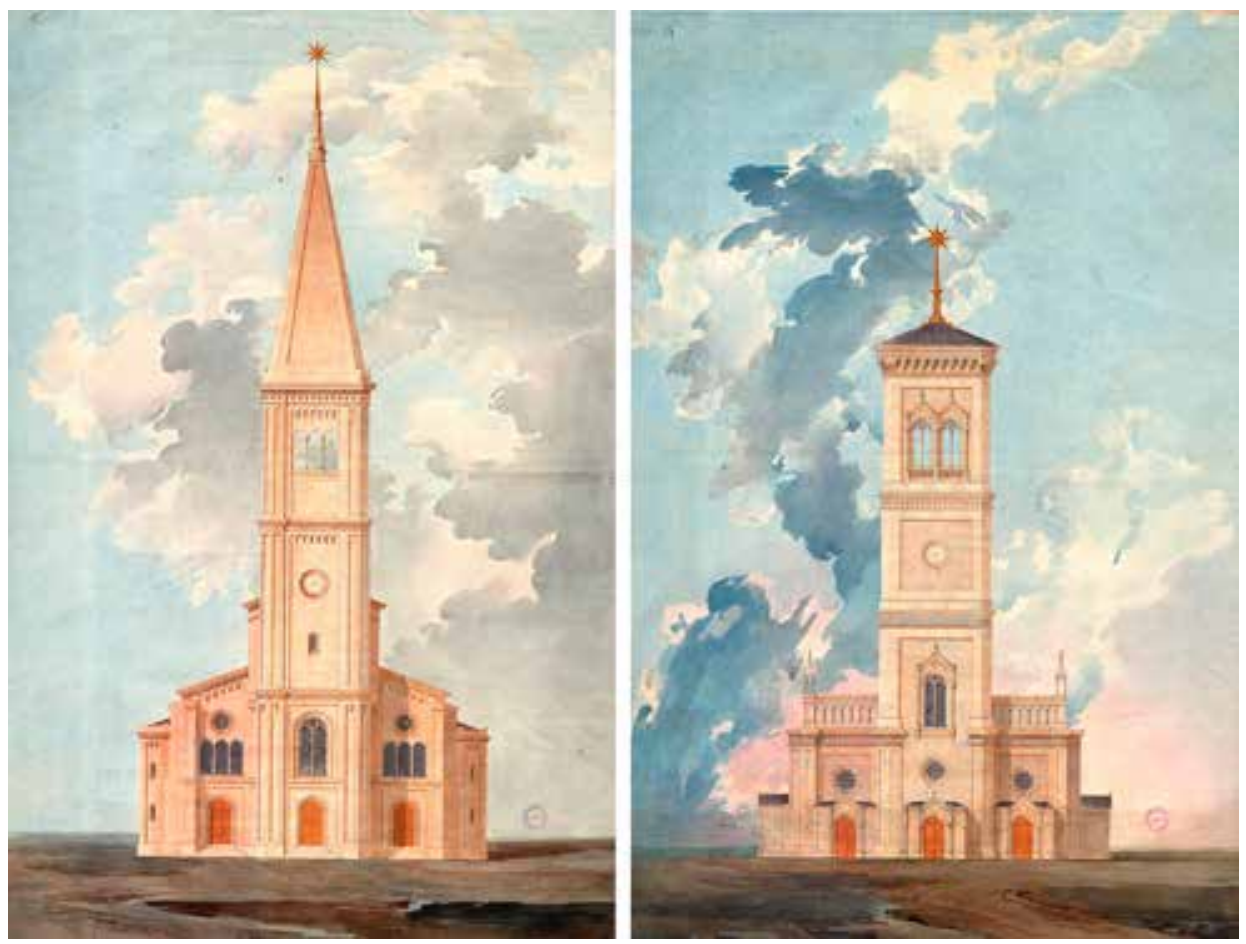

3. kép. A debreceni református kistemplom neoromán (balra) és neogótikus (jobbra) jegyeket mutató homlokzati tervváltozatai. Pollack Ágoston, Ybl Miklós. Forrás: TtREL II.29.c. 5, 14

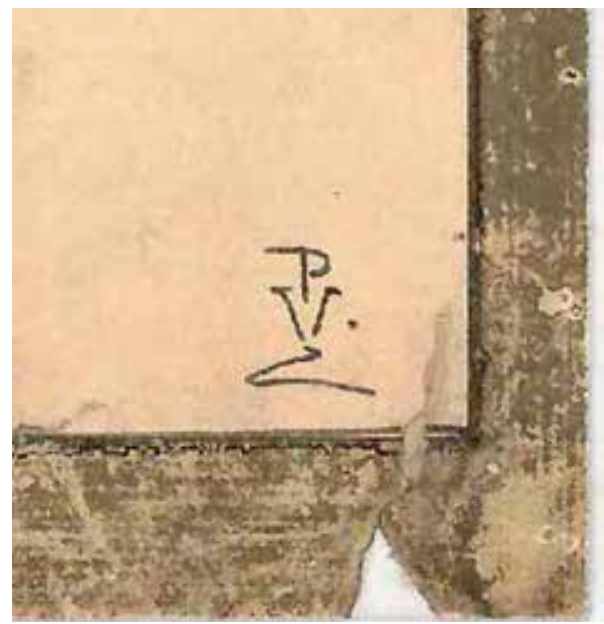

4. kép. Pollack Ágoston és Ybl Miklós közös szignója. Forrás: BFL XV.17.f.331.b 4/14 
A fiatal Prokopp János (1825-1894) 1843 tavaszán egy hónapig az Építészeti Intézet munkatársa volt. ${ }^{93} \mathrm{Ybl}$ Ervin az építésziroda kevés megrendelésével magyarázza, hogy bő másfél év múltán ismét hirdetést adtak fel a Pesti Hírlap hasábjain. ${ }^{94}$ „Épitészeti Intézet.

Az alulirottak építészeti intézete, Dorottya utcában Vogl-féle házban, 16 szám alatt mindennémü épitészeti tervek költségfelszámolások készitésével, urasági lakok butorzásával foglalkozik; magokat a' m. uraságoknak 's nem csak a' testvér városok, hanem az egész ország 's kapcsolat részek építeni kivánó t. cz. lakosainak szivesen megbizásaik pontos teljesitésére ajánlván.

Pesten, Augusztusban, 1843 Pollack Ágoston építőmester, Ybl Miklós építész."

Érdekes egybeesés ugyanakkor, hogy erre a hirdetésre Pollack Mihály 70. születésnapjának hónapjában került sor, éppen amikortól a mester nem vállalt több munkát, megbízásait, mühelyét pedig fia és a napilapban feladott hirdetés tanúsága szerint legjobb tanítványa, Ybl Miklós vitte tovább. ${ }^{95}$

A Pollack és Ybl aláírásával ellátott munkák közé tartoznak a nagykárolyi, Károlyi tulajdonban levő Aranyszarvas Szálló táncteremmel való bővítésének tervei is 1845 ből. ${ }^{96}$ A szignó felfedezhető még a szintén Károlyi megbízásból készülő fóti római

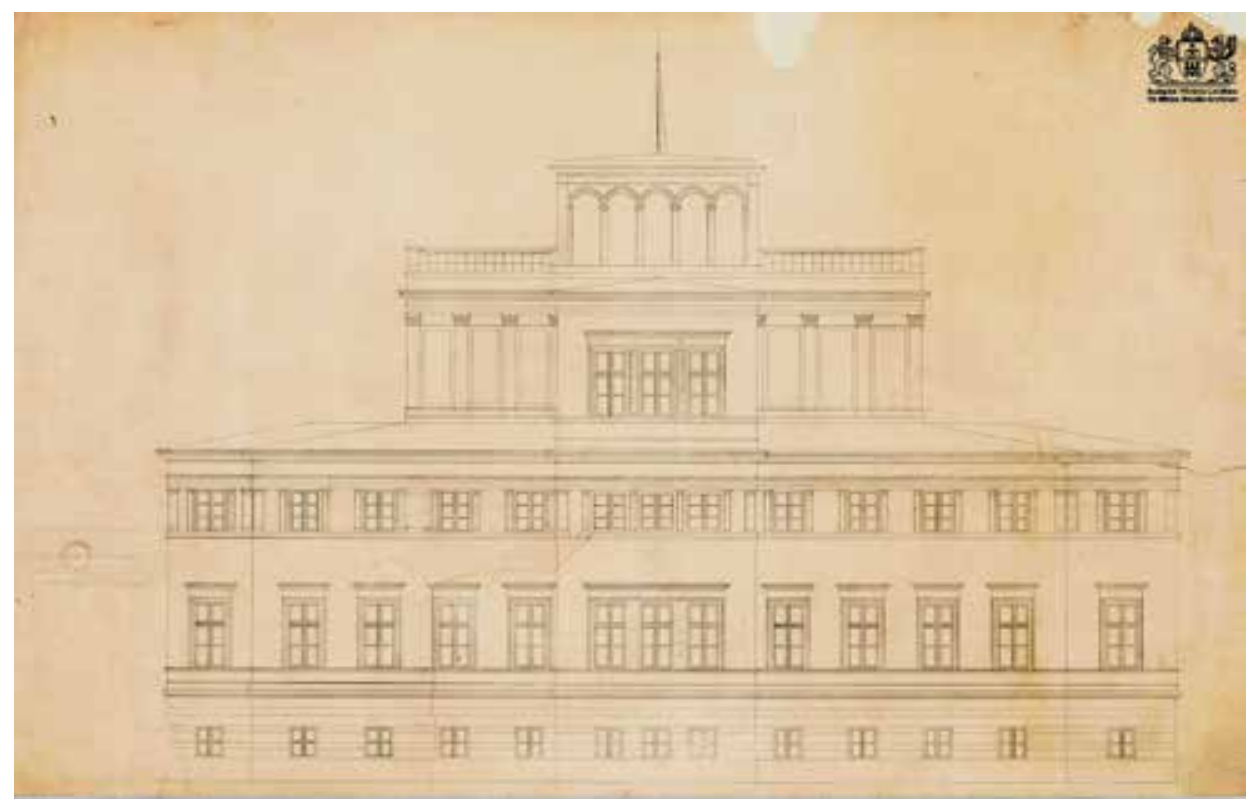

5. kép. Az ikervári Batthyány-kastély hátsó homlokzatának terve. Pollack Ágoston, Ybl Miklós. 1845. Forrás: BFL XV.17.f.331.b 92/1

\footnotetext{
${ }^{93}$ Prokopp 1981. 137-138; Prokopp 1994. 2. Vándorkönyvébe Pollack Ágoston jegyzett be.

${ }^{94}$ Pesti Hirlap 1843. augusztus 13. (273. sz.) 550.

${ }^{95}$ Bibó 2008. 115.

${ }^{96}$ BFL XV.17.f.331.b - 19/4-9.
} 
katolikus templom és plébánia korai alaprajzán és ablakának részlettervein, ${ }^{97}$ valamint a vélhetően szintén a fóti Károlyi-kastély 1840-es évekbeli átépítéséhez köthető korai alaprajzi tervváltozaton is. ${ }^{98}$ Legjelentősebb és egyben legismertebb közös munkájuk az 1846-1847 között épült ikervári Batthyány-kastély nagyszabású átépítése $^{99}$ (5. kép). A Schinkel klasszicizmusát és római hatásokat mutató építmény a magyar kastélyépítészet egyik kiemelkedő alkotása. ${ }^{100}$ Stílusa összefüggésbe hozható Ybl 1845-1846 folyamán tett újabb itáliai tanulmányútjával, amelynek során a római építészeti emlékek, paloták, villák tanulmányozására is jutott ideje. Ismert továbbá három eltérő kastélyalaprajz, melyeket korábban a szakirodalom Ybl Ervin nyomán a fóti Károlyi-kastély korai tervváltozatainak tartott, ${ }^{101}$ azonban Ritoók Pál újabb kutatásai alapján ${ }^{102}$ e kapcsolat erősen megkérdőjelezhető, így azonosítatlannak tekinthetök. ${ }^{103}$

Ezzel le is zárul azon müvek köre, melyek kétséget kizáróan kettejük tevékenységének eredményeként jöttek létre. A két építész társas viszonya megszünésének időpontja nem ismert. Ybl Ervin szerint csupán két-három évig tartott, mivel Ybl 1843-tól már egyedül kapta meg a Károlyi család megbízásait, ${ }^{104}$ ez azonban - mint látható - nem teljesen igaz, és kettejük együttmüködése bizonyíthatóan tovább tartott ennél. Inkább a kortárs Neÿ Béla (1843-1920) állításával érthetünk egyet, mely szerint 1841 és 1846 között voltak társak, de még 1849-ig eseti munkakapcsolatban álltak ${ }^{105}$ (2. táblázat).

\section{KÖZÖS MÜKÖDÉSÜK IDEJE ALATT KÉSZÜLT ÖNÁLLÓ MUNKÁIK}

Érdemes megvizsgálni a két építész 1840-es években készült egyéb terveit is, melyek esetében ugyan semmiféle forrás nem erősíti meg, hogy az adott munkákon közösen dolgoztak volna, mégis kapcsolatba kerülhettek egymás megbízóival és megbízásaival.

${ }^{97}$ BFL XV.17.f.331.b - 4/14; 251.

${ }^{98}$ BFL XV.17.f.331.b - 10/2.

${ }^{99}$ Ybl 1956a. 13-14; Ybl 1991. 152-153; Ybl 2002. 49-50; Sisa 2013. 280.

${ }^{100}$ Sisa 2007. 145-146.

${ }^{101}$ Ybl 1956a. 17-18.

${ }^{102}$ Ritoók 2007. 203-205. Itt köszönöm meg Ritoók Pál szóbeli közléseit a fóti kastély építéstörténetével kapcsolatban.

${ }^{103}$ BFL XV.17.f.331.b - 10/3. U alaprajzú emeletes kastély földszinti alaprajza, hozzá kapcsolódó fürdő- és konyhaépületekkel. Keresztmetszetére Ritoók Pál hívta fel a figyelmemet: BFL XV.17.f.331.b - a12/5. 10/4. H alaprajzú kastély földszinti alaprajzváltozata („Projekt II.”), hozzá kapcsolódó fürdőépülettel, valamint konyhaépülettel egybeépült vendégházzal. 10/5. H alaprajzú kastély földszinti alaprajzváltozata („Projekt III.”), hozzá kapcsolódó konyhaépülettel egybeépült vendégházzal.

${ }^{104}$ Ybl 1956a. 18; Ybl 1991. 23.

${ }^{105}$ Neÿ 1879. 
2. táblázat. A Pollack Ágoston és Ybl Miklós együttmüködésével tervezett és megvalósult munkák

\begin{tabular}{|c|c|c|}
\hline Év & Munka megnevezése & Megjegyzés \\
\hline $1841-1843$ & $\begin{array}{l}\text { Josephinum fiúárvaház, Pest, Üllői út } \\
\text { (kivitelezés) }\end{array}$ & Bibó István szerint Pollack Mihály terve \\
\hline $1841-1842$ & $\begin{array}{l}\text { Református Nagytemplom, Debrecen } \\
\text { (terv) }\end{array}$ & Három tervalternatíva kidolgozása \\
\hline 1841 után & Károlyi-kastély, Fót (?) (terv) & $\begin{array}{l}\text { Bizonytalan, hova készült a fennmaradt terv. } \\
\text { Heinrich Koch tervei nyomán épült át a fóti } \\
\text { kastély, az } 1840 \text {-es években valóban } \\
\text { Ybl fejezte be }\end{array}$ \\
\hline 1842 & $\begin{array}{l}\text { Református Kollégium bővítése, Debrecen } \\
\text { (terv) }\end{array}$ & Anyagi okokból kivitelre nem került \\
\hline 1842 & $\begin{array}{l}\text { Református Kollégium befejező munkái, } \\
\text { oratórium mennyezet (megépült) }\end{array}$ & $\begin{array}{l}\text { Povolny Ferenc kivitelezte. 1887-ben } \\
\text { elpusztult }\end{array}$ \\
\hline $1844-1845$ & $\begin{array}{l}\text { Református Nagytemplom, Debrecen } \\
\text { (megépült) }\end{array}$ & $\begin{array}{l}\text { Povolny Ferenc módosításai nyomán csak } \\
\text { a fedélterv került kivitelre }\end{array}$ \\
\hline 1845 & $\begin{array}{l}\text { Aranyszarvas szálló táncteremmel való } \\
\text { bővítése, Nagykároly (megépült) }\end{array}$ & A Károlyi család megbízásából \\
\hline $1845(-1854)$ & Római katolikus templom, Fót (megépült) & $\begin{array}{l}\text { Közös szignójuk korai alaprajzi vázlatokon és } \\
\text { részletterveken is }\end{array}$ \\
\hline $1846-1847$ & $\begin{array}{l}\text { Batthyány-kastély átalakítása, Ikervár } \\
\text { (megépült) }\end{array}$ & Az épület nagyarányú átalakítása \\
\hline $\begin{array}{l}\text { ismeretlen } \\
\text { időpont }\end{array}$ & azonosítatlan kastélytervek (?) & $\begin{array}{l}\text { Három földszinti alaprajz (kettő bizonyosan } \\
\text { egymás alternatívája) és az egyikhez kapcso- } \\
\text { lódó metszet az Ybl-hagyatékban }\end{array}$ \\
\hline
\end{tabular}

Yblnek a Károlyi családdal való viszonya ebben az időszakban erősödött meg. 1841-ben Károlyi György megbízta Yblt a Kaplonyban ${ }^{106}$ álló, földrengésben megrongálódott templom és kolostor helyreállító felújításával. ${ }^{107} 1844$-től a család fehérvárcsurgói kastélyán egykori mestere, Heinrich Koch terveinek megvalósításában müködött közre. Hasonló szerep jutott neki legkorábban 1845-től három éven át a család fóti kastélyánál is, ahol a kastély Heinrich Koch tervei nyomán történt nagyszabású átépítésének befejező munkálatait felügyelhette. ${ }^{108}$ Ugyanebben az időszakban már ő kapta meg a megbízást az ottani plébániatemplom és benne a családi kripta megtervezésére. Ybl 1846-ban Fótra költözött, és a következő évben gróf Károlyi István uradalmi építésze lett. ${ }^{109}$ Pestre csak 1851-es házasságkötését követően költözött vissza. ${ }^{110}$ Mint láthattuk, e munkák közül egyes esetekben Pollack Ágoston valamilyen szintủ közremüködése is vélelmezhető.

${ }^{106}$ Ma Căpleni, Románia.

${ }^{107}$ BFL XV.17.f.331.b - 5/1.

${ }^{108}$ Carl Burg jószágigazgató 1849-es ajánlólevele nyomán (MNG Adattár 1691/1922 Ybl Miklós). A levelet és magyar fordítását idézi: Ritoók 2007. 205.

${ }^{109}$ Ybl 1991. 197.

${ }^{110}$ MNL OL, Miniszterelnökségi Iratok K 26 1844/1882. sz. 
Ha a Pollack Ágoston neve alatt ebben az időszakban engedélyeztetett terveket vizsgáljuk, azok közt alig található nagyobb új építkezés. ${ }^{111}$ Azonban Zádor Anna értékítélete túlzottan szigorúnak tünik, a számos terv közt nem csak ,sivár, az építőmesteri munka szintjén álló alkotások" találhatók, ${ }^{112}$ megfigyelhetők egyedi megoldások is. Ilyen például az 1841-ben a Dohány és Mező (ma Klauzál) utca sarkára, Beretvás A. számára tervezett földszintes épület szélső tengelyeiben megjelenő, félköríves záródású ikernyílások és azok keretezése. ${ }^{113}$ 1842-ből figyelemre méltó a Nyár utcában testvére, Pollack Magdolna férjének, Unger Antalnak tervezett épület teljes egészében kváderezést imitáló felületü homlokzatképzése. ${ }^{114}$ Méretével emelkedik ki a Gránátos (ma Városház) utcában Piskovits János megrendelésére emelt háromemeletes ház, egy félbehagyott építkezés legkorábban 1843-ban elkészült befejezése. ${ }^{115}$ Pollack Ágoston ebben az évben engedélyeztette az első pesti gyermekmenhely egyemeletes épületét is, mely inkább funkcióját, mint építészeti meg-

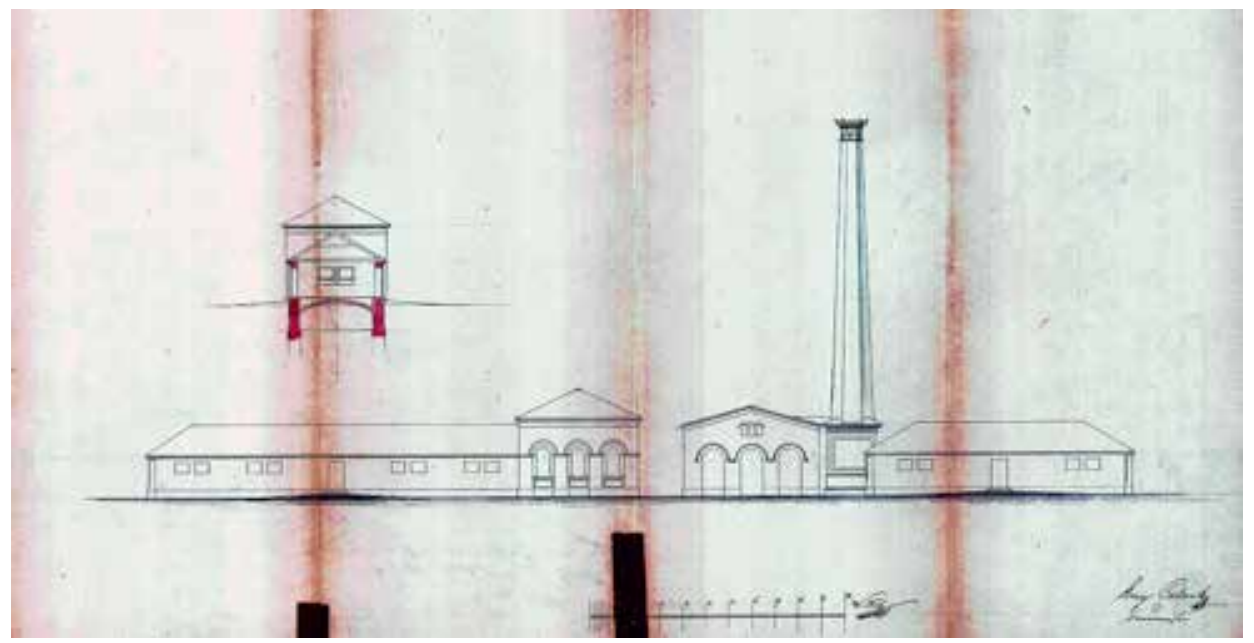

6. kép. A lipótvárosi cukorfinomító épületegyüttese. Pollack Ágoston, 1845.

Forrás: BFL XV.17.b.331 SzB 11011-d

${ }^{111}$ Bierbauer 1932. 94.

${ }^{112}$ Zádor-Rados 1943. 90.

${ }^{113}$ BFL XV.17.b.331. SzB 9037 a-c. Az épületre 1868-ban egy szintet ráépítettek Lohr János tervei szerint (BFL XV.17.b.312 431/1868). A 20. század közepe táján lebontották, ma üres telek. Mai cím: VII. Dohány utca 35 .

${ }^{114}$ BFL XV.17.b.331 SzB 9502 a-c. Az épületre 1933-ban részlegesen emeletet építettek. (Déry 2006. 343.) 2000 körül lebontották, helyén 2000 után épült irodaház áll. Mai cím: VII. Klauzál utca 12., Nyár utca 11.

${ }^{115}$ BFL XV.17.b.331. SzB 9938 a-f. Az épületet 1910 körül lebontották. (Déry 2005. 384-385.) Mai cím: helyén a Pilvax köz. 
formálását tekintve jelentős. ${ }^{116} 1845$-ösek a lipótvárosi cukorfinomító üzemépületeinek tervei ${ }^{117}$ (6. kép). 1846-ból származik Gratzl Ferenc lipótvárosi sétatéren álló háza háromemeletessé bővítésének és átalakításának a terve; Pollack a felső, alacsonyabb belmagasságú szintjét egyenes szemöldökpárkány alatt egymáshoz kapcsolt félköríves nyílásokkal oldotta meg, érdekes továbbá az állókonzolos zárópárkány is ${ }^{118}$ (7. kép). 1846-ban elöbb egy jelentéktelenebb belső átalakítást végzett a volt

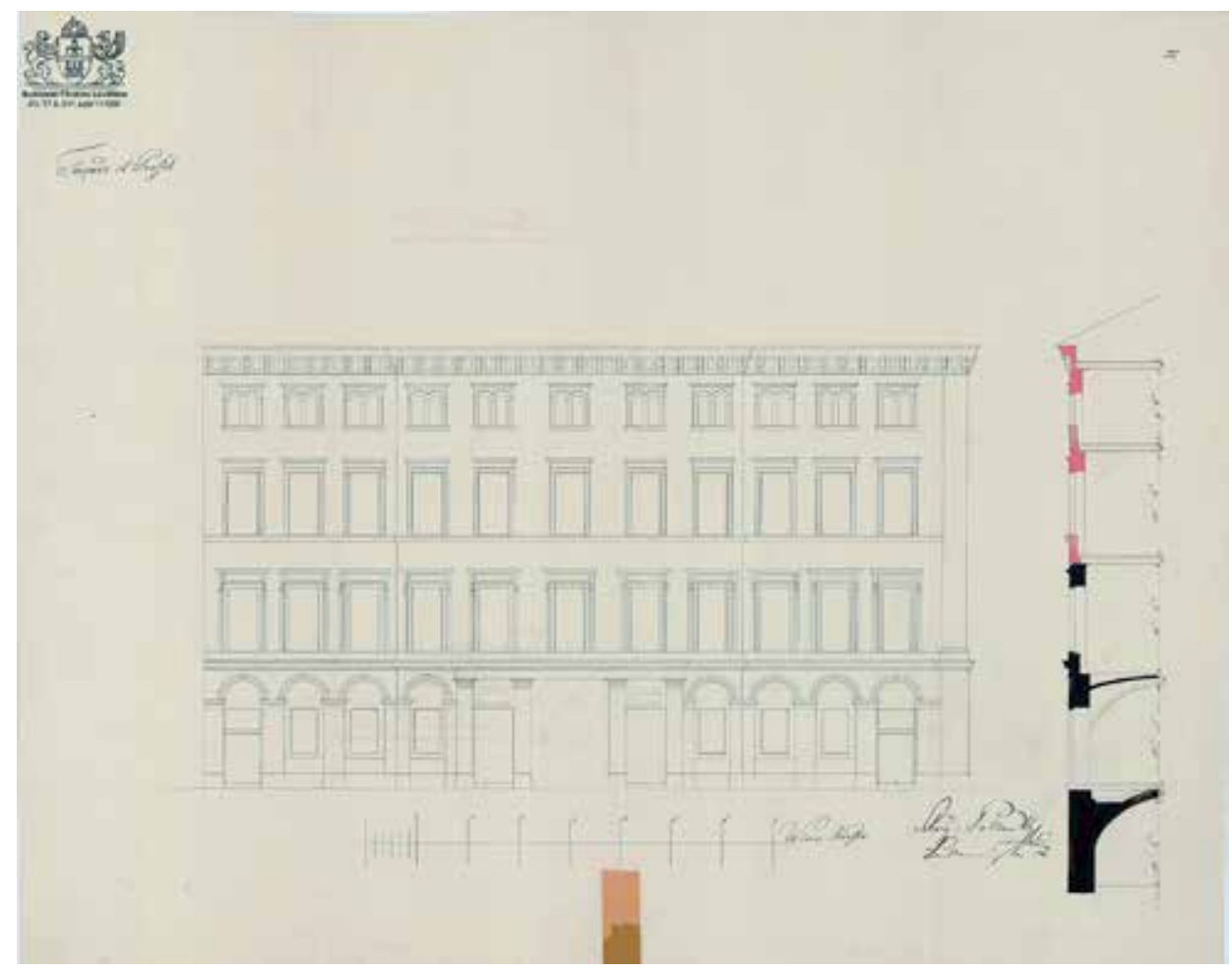

7. kép. Gratzl Ferenc háza. Pollack Ágoston, 1845. Forrás: BFL XV.17.b.311 SzB 11159-f

${ }^{116}$ BFL XV.17.b.331. SzB 10146 a-d. Az épület helyét nem sikerült azonosítani, utóbb bizonyosan lebontották. Mai cím: V. Stollár Béla utca vagy VII. Kürt utca (korábban mindkét utca Valero utca).

${ }^{117}$ BFL XV.17.b.331 SzB 11011 a-d. Az egész tömböt elfoglaló épületegyüttest a nagykörúti bérházépítkezések miatt az 1880-as évek folyamán elbontották. Mai cím: V. Nyugati tér - Bajcsy-Zsilinszky út - Stollár Béla utca - Bihari János utca által határolt tömb.

${ }^{118}$ BFL XV.17.b.331 SzB 11159 a-k. Az épületet 1904-1905 folyamán szecessziós stílusban átalakították Sámuel Lajos tervei nyomán. (Déry 2005. 240.) 2005-10 között további két szintet építettek rá Reimholz Péter és Nagy Péter tervei nyomán. (Reimholz Péter utolsó munkája, hozzáférés: http://epiteszforum.hu/reimholz-peter-utolso-munkaja. Utolsó megtekintés: 2017. 01. 15.) Mai cím: V. Október 6. utca 26., Szabadság tér 4. 


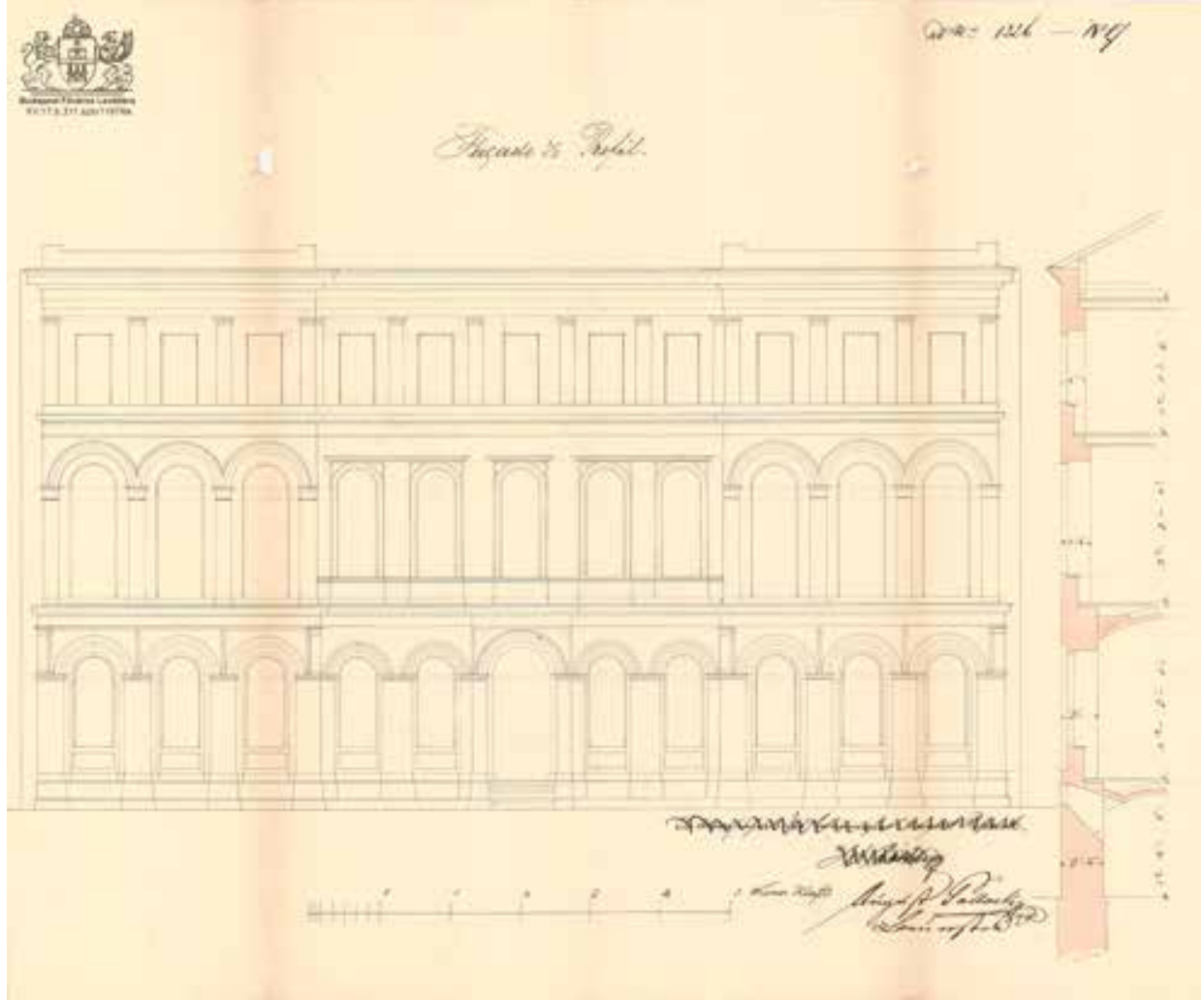

8. kép. Vendelin Péter háza. Pollack Ágoston, 1846. Forrás: BFL XV.17.b.311 SzB 11976-e

klarissza kolostorból korábban kialakított Pesti Királyi Főzálogház épületén, ${ }^{119}$ majd egy évvel később, miután a teljes épület birtokába jutott az intézmény, annak átalakítását kivitelezte. ${ }^{120}$ Másfél évtizeddel korábban apja már dolgozott ugyanezen az épületen. ${ }^{121}$ Részleteiben érett klasszicista, tömegében már a romantika sarokhangsúlyaival élő épülete a Vadász és Hajnal (ma Nagysándor József) utca sarkán álló, Vendelin Péternek 1846-1847-ben épített ház, melynek első emeletén a jobb oldalon - a tervek szerint - díszterem is helyet kaphatott ${ }^{122}$ (8. kép). 1847-ből származnak a kereskedő egylet nyugdíj- és betegalapja kórházának tervei, melyeken romantikus,

${ }^{119}$ BFL XV.17.b.331 SzB 11422 a-b. Központi zálogház, ma az ELTE adminisztrációs épülete, műemlék. Mai cím: V. Szerb utca 21-23.; Királyi Pál utca 1-3.

${ }^{120}$ BFL XV.17.b.331 SzB 11945 a-e. A figyelmet felhívja rá: Bibó 1977. 210.

${ }^{121}$ Bibó 1977. 209-210.

${ }^{122}$ BFL XV.17.b.3 31 SzB 11976 a-e. Ma is áll, müemlék (1997). Mai címe: V. Nagysándor József utca 8., Vadász utca 21. 


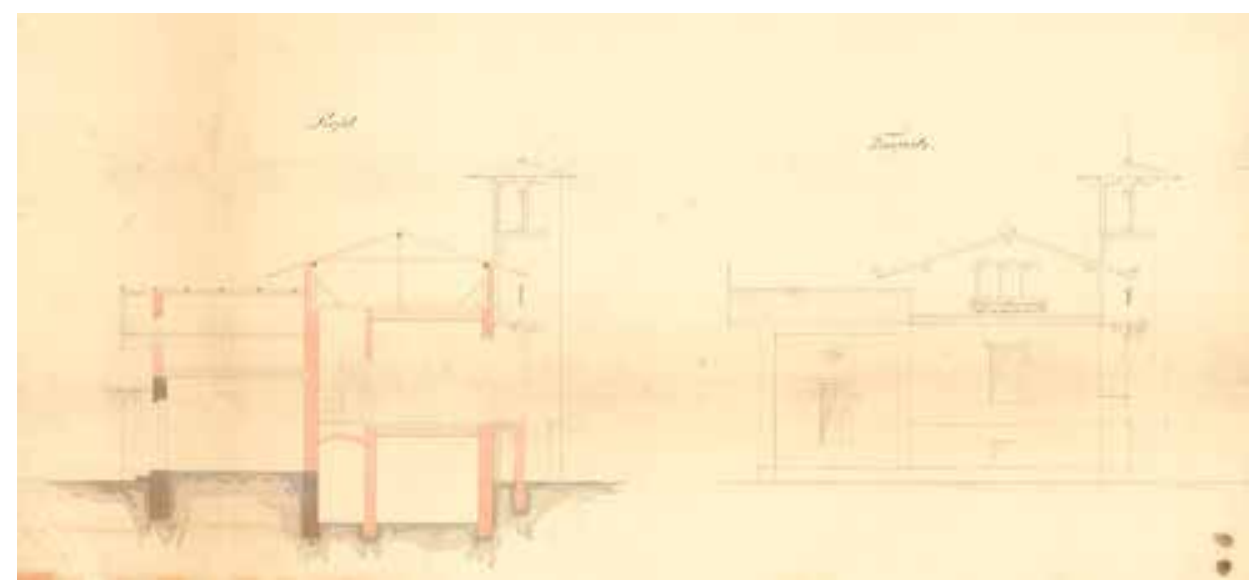

9. kép. A Vankó-villa hosszmetszete és oldalhomlokzata. Pollack Ágoston, 1846. Forrás: BFL XV.17.b.311 SzB 11522

részben gótizáló architektúra látható. ${ }^{123}$ Lebegő szemöldökpárkány megoldása már az apja számára 1846-ban tervezett feldunasori „svájci házon” is megjelent. ${ }^{124}$

Gábor Eszter hívta fel a figyelmet a „társ nélküli”, Városligeti fasori, egykori Vankó-villára, amely 1846-ban valósult meg, mint a fasor egyik korai, klasszicista tömegalakításon túllépö, tornyos nyárilakja ${ }^{125}$ (9. kép). Gábor az 1835-1836-os potsdami Villa Jakobsszal és az 1843-as Villa Schöningennel (mindkettő Ludwig Persius műve) hozza összefüggésbe. A Vankó-villával kapcsolatban Ybl szerzősége nem merült fel, azt egyedül Pollack Ágoston nevéhez kötik. ${ }^{126}$ A Toscanából származó, könnyed, tornyos épülettípus német közvetítéssel jutott el Magyarországra, szintén Schinkelt és a Potsdamban itáliai mintákra épülő villák világát idézve. Ybl életmüvében az efféle aszimmetrikus tornyos megoldás inkább a kastélyoknál volt kedvelt, ${ }^{127}$ kevés számú villaépülete közt a Margit-szigeti fürdőtelep nagyvillájánál (1869-70 körül) és a komplexumhoz tartozó Nagyvendéglőnél (1867-1870) fordult elö, valamint hagyatékának azonosítatlan tervlapjai közt. ${ }^{128}$

1847-ben Pollack Ágoston írta alá a pesti romantikus építészet egyik legjelentősebb müveként számon tartott, Brein Ferenc (1817-1879) által tervezett, a Király utca, Kis Mező (ma Csányi) utca sarkán álló Pekáry-ház terveit. ${ }^{129} \mathrm{~A}$ Brein családdal

${ }^{123}$ BFL XV.17.b.331 SzB 11609. Az épületet utóbb bővíthették, majd a Royal Szálló (Ray Rezső, 1895-96) építése miatt lebontották. Mai címe: VII. Hársfa utca 50-52.

${ }^{124}$ BFL XV.17.b.331 SzB 11194 a-c. A 19-20. század fordulójáig állhatott. Mai közelítő cím: XIII. Pozsonyi út 21. körül.

${ }^{125}$ Gábor 2004. 212-213.

${ }^{126}$ Uo.; Gábor 2010. 125; Sisa 2013. 287.

${ }^{127}$ Sisa 2014. 556-557.

${ }^{128}$ BFL XV.17.f.331.b a13/13a, b, c, d.

${ }^{129}$ BFL XV.17.b.331 SzB 11866. Ma is áll, műemlék. Mai cím: VII. Király utca 47., Csányi utca 12-14. 
Pollack Ágoston régebb óta együttmüködött. A Brein Ignác (1787-1834) özvegye, Brein Magda neve alatt futó tervekért - melyeket vélhetően Ferenc készíttetett Pollack Ágoston vállalt felelősséget. ${ }^{130} 1849$-ben is ő építette rá a 3. emeletet az apja által a család számára tervezett és kivitelezett, a mai József Attila utcában álló Pollack-házra. ${ }^{131}$

\section{POLLACK ÁGOSTON TOVÁBBI ÉLETPÁLYÁJA}

Pollack Ágoston életútja az 1850-es évben vált el Ybl Miklósétól. Unokája, Pollack Ella szerint Ágoston apja haláláig, 1855-ig az idős mester mellett dolgozott. ${ }^{132}$ Minthogy Pollack Mihály 70 éves korát követően csak a Nemzeti Múzeum befejezésén dolgozott, e megjegyzés leginkább úgy értelmezhető, hogy a fiú és az apa egymás támogatásával dolgozhattak, talán irodájukat is megosztották. Pollack Ágoston aláírásra feljogosító céhmestersége miatt nehéz elválasztani egymástól a tervezési-kivitelezési és a csak kivitelezési munkáit. Forrásokból tudjuk, hogy utóbbira is számos alkalommal vállalkozott. Ö volt a budai várbéli királyi istállóépületnek az építöje 1852-1854 között, melynek megvalósítása az 1848-1849-es események miatt félbeszakadt. ${ }^{133}$ Ő végezte az ehhez közel eső, úgynevezett Stöckl-épület kivitelezését is a palota szomszédságában. ${ }^{134} \mathrm{Az} 1850$-es években az Általános Osztrák Légszesztársulat tervező és kivitelező építésze is ő volt, és részt vett a józsefvárosi gázgyár létesítésében, amelynek több, általa tervezett épülete a mai napig is áll. ${ }^{135}$

Pollack Ágoston későbbi tevékenységéről az Építő Bizottmány anyaga ad számot. Az 1863-as és 1864-es évek anyagában összesen 199 olyan terv található, amelyet ő szignált. A hatalmas mennyiség ellenére túlnyomó többségükben olyan munkákról van szó, amelyek az építészettörténet-írás számára érdektelenek. Nyílt színek, szerény toldalékok földszintes épületekhez, belső átalakítások, elfalazások, alig akad egy nagyobb szabású építkezés köztük, önálló, földszintes házból sincs köztük több mint két tucat. Működésének súlypontja ekkor a mai Nagykörút vonalán kívül eső Erzsébet-, Teréz-, József-, és Ferencváros területe volt. Az épületek döntően egyszerü, a kései klasszicizmus homlokzatképzésén túl nem lépő alkotások, melyekre jóval inkább igazak Zádor Anna korábban idézett szavai. Kivételt képez az 1862-ben a Magyar utcába Lipp Ferenc számára tervezett, valószínúleg meg nem valósult kéte-

${ }^{130}$ Bierbauer 1932. 78, 85 .

${ }^{131}$ Bibó 2008. 98.

${ }^{132}$ Lyka 1933. 57.

${ }^{133}$ Ybl 1956b. 320. Kőműves- és elhelyező munkáért 109000 forintot kapott. Zitterbarth Mátyás helyét vette át. (Farbaky 2003. 153.) Az 1850-es évek végére teljesen elkészült épületet 1901-1903 között Hauszmann Alajos építette át. A II. világháborúban súlyosan megrongálódott, és 1954-ig teljesen elbontották. (Farbaky 2001. 258-259.)

${ }^{134}$ Ybl 1956b. 318. Joseph Weiss tiltakozott szerepvállalása ellen, lassúságára és megbízhatatlanságára hivatkozva. Az épületet Hauszmann teljesen lebontatta, helyére 1901-1903 között épült fel a Várbéli Főőrség épülete. (Farbaky 2001. 258.)

${ }^{135}$ Vadas 2007. 92. 1860-tól Diescher József vette át a helyét. 


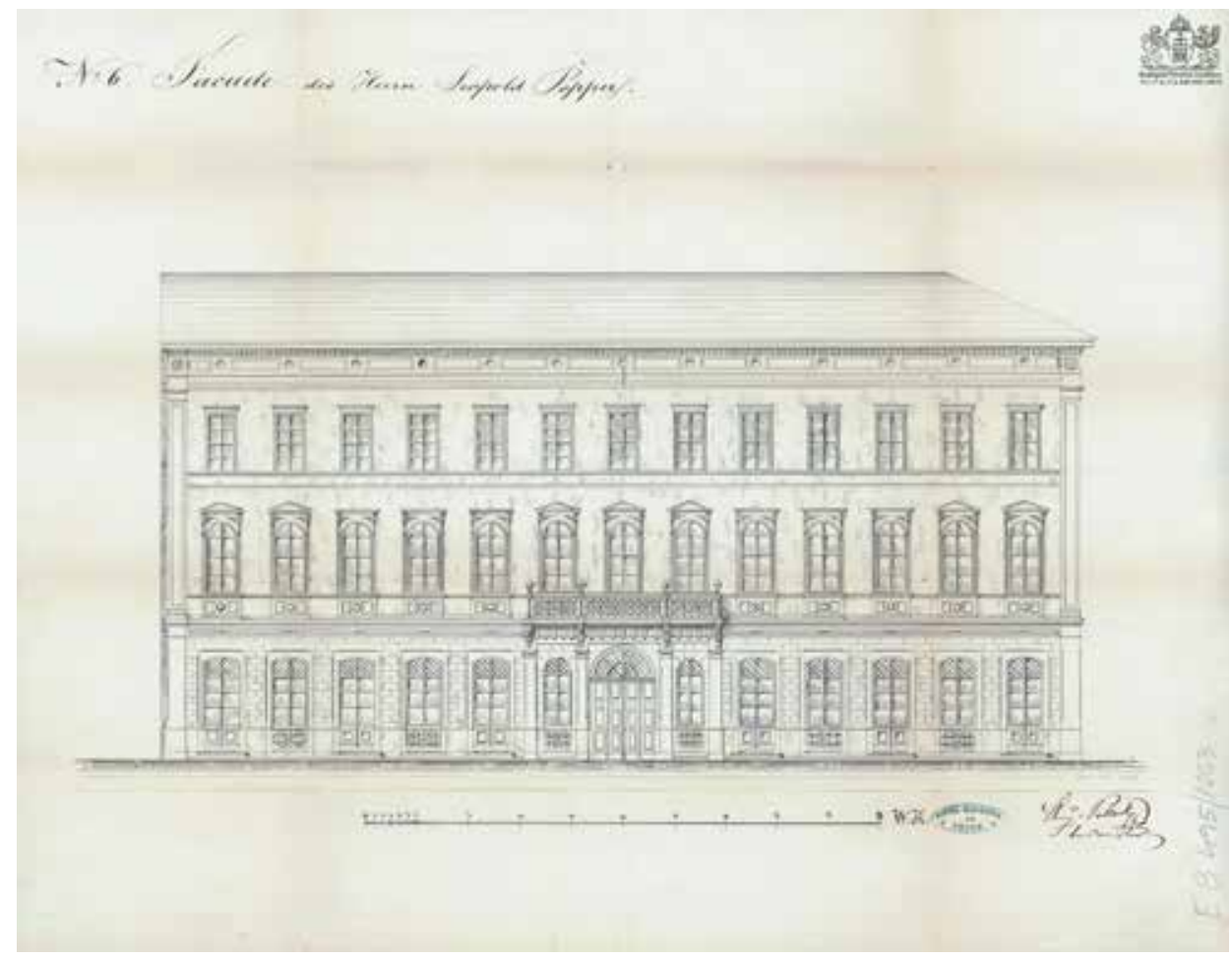

10. kép. Popper Lipót háza. Pollack Ágoston, 1863. Forrás: BFL XV.17.b.312 ÉB 495/1863

meletes lakóháza ${ }^{136}$ kései romantikus architektúrájával, valamint az 1863-ban a Váci (ma Bajcsy-Zsilinszky) útra, Popper Lipót faiparos részére tervezett, hasonló jellegü kétemeletes bérháza. ${ }^{137} \mathrm{Ez}$ utóbbi ebben a formájában nem épült meg, az építkezés minden valószínűség szerint félbemaradt, és azt végül Hild Károly (1803-1887) fejezte be ${ }^{138}$ (10. kép).

Pesti tervezéseinek és kivitelezéseinek megszünésére 1864-től Pollack Ella viszszaemlékezéséből kapunk választ. ${ }^{39}$ Pollack Ágoston a hatvanas évek közepén müködése súlypontját vidékre tette át. Mint építési vállalkozó dolgozott a Tiszavidéki

\footnotetext{
${ }^{136}$ BFL XV.17.b.312 149/1862. Kataszteri térképek alapján a beépítés alakja nem egyezik. A telken jelenleg ismeretlen tervező 1913-14 folyamán megvalósult épülete áll. (Déry 2005. 181.) Mai címe: V. Magyar utca 27.

${ }^{137}$ BFL XV.17.b.312 495/1863. Nem valósult meg. Mai címe: V. Bajcsy-Zsilinszky út 74., Markó utca 33.

${ }^{138}$ BFL XV.17.b.312 26/1864. Az építtető Popper Lipót új, Hild Károly által szignált terveket nyújtott be. Ezek az udvari keresztszárny kivételével megvalósultak, azt 1865-ben Frey Lajos (1817-1877) és Gerster Károly (1819-1867) tervei nyomán (79/1865) építették meg, majd 1872-ben épült rá a harmadik emelet Buzzi Bódog (1829-1875) tervei nyomán (231/1872). Jelenlegi alakját ismeretlen tervezőtől a 20. század első évtizedében nyerte el. Mai címe: V. Bajcsy-Zsilinszky út 74., Markó utca 33.
}

${ }^{139}$ Lyka 1933. 57. 
és Erdélyi vasutak építésénél is. Unokája leírása szerint azonban „vállalkozásaiban nem volt szerencsés, mert inkább müvészvér volt, semmint üzletember". Bibó István azt valószínűsíti, hogy apja hagyatékának jelentős része Ágoston tulajdonából szóródott szét. ${ }^{140}$ 1872-ben halt meg, 65 évesen a Bihar vármegyei Bél ${ }^{141}$ községben.

\section{YBL ÉS A POLLACK CSALÁD KAPCSOLATA}

Ybl Miklós munkásságában a Pollack családhoz való kötődését még több ponton is ki lehet mutatni. Unger Henrik (1809-1877) 1852-1853 között épült, Múzeum körúti bérházát, első teljesen önálló pesti munkáját egykori mestere veje testvérének tervezte. A megbízás bizonyára nem volt független a Pollackokkal való kapcsolattól. ${ }^{142}$ 1863-ban az addig kitartóan a Pollackokkal terveztető Dlauchy család egyik tagja, Károly (1817-1901) már Ybllel terveztette meg mai Vámház körúton álló házát. Az építész és a megrendelő már Ybl Pollack Mihály irodájában töltött éveiböl is ismerhette egymást, azonban valószínűleg nagyobb jelentósége volt annak, hogy később munkakapcsolatba is kerültek a fóti templom építésénél, ahol Dlauchy a lakatosmunkákon dolgozott. ${ }^{143} \mathrm{Az} 1860$-as évek elején a Nemzeti Múzeum részéről is Yblt bízták meg a Pollack Mihály által tervezett épületben szükségessé váló munkákkal, a Széchenyi-terem, majd a múzeumban helyet kapó ideiglenes felsőház kialakításával, utóbb az épület körüli kert kerítésének megtervezésével. ${ }^{144}$ Vélhetően emiatt a megbízás miatt, és nem az 1830-as években betöltött - jelentősnek biztosan nem tekinthetö - közremüködése miatt voltak egy ideig Yblnél az épület eredeti tervei, ahogyan szintén ő őrizte Pollack egyik, 80 éves kora körül készült rajzát is, melyet vagy magától a mesterétől, vagy a családtól kaphatott ajándékba. ${ }^{145} 1855$. január 5-én, 82 éves korában hunyt el Pollack Mihály. Később a tahitótfalui temetőben Ybl tervei nyomán emeltek számára díszes síremléket, ${ }^{146}$ aki személyes nyilatkozatai révén is hozzájárult Pollack emlékének fenntartásához, ápolásához. ${ }^{147}$ A családdal való jó viszonyát mutatja, hogy Ybl örökbe fogadta Pollack Mihály elárvult unokáját, Máriát. ${ }^{148}$

${ }^{140}$ Bibó 2008. 167.

${ }^{141}$ Ma Beliu, Románia, Arad megye.

${ }^{142}$ Hidvégi 2014. 47.

${ }^{143}$ Marótzy 2014. 69.

${ }^{144}$ Debreczeni 2014. 30-36.

${ }^{145} \mathrm{Ybl}$ kijelentése szerint e terveket a hivatkozott cikk megjelenésekor már egy felszólítás hatására átadta a Kultuszminisztériumnak. (H. Gaál 1891. 3.)

${ }^{146} \mathrm{Ybl} \mathrm{1956a.} 44$.

${ }^{147}$ H. Gaál Adorján 1891-es cikke megírásakor Ybl Miklóshoz fordult Pollack Mihály életmüvére vonatkozó adatokért. ,...a Polláck életrajzára vonatkozó adatokat Ybl mesterünk lekötelező szívességéből állíthattam össze, aki azokat emlékezetből összeszedvén, tollba mondotta.” (H. Gaál 1891. 3.)

${ }^{148}$ Nem tudjuk bizonyosan, hogy Pollack Mária Pollack Mihály melyik gyermekének lánya volt. (Zádor 1952. 17; Ybl 1956a. 197.) Létezik egy 1889 körül készült fénykép, melyen Ybl Miklósné, Pollack Mária és egy azonosítatlan személy látható. (Ybl 1991. 200., kat. C.2.5.) 


\section{ÖSSZEGZÉS}

Ybl Miklósnak a Pollack családdal való szoros viszonya és együttmüködése komoly szerepet játszott pályája alakulásában. Ágostonnal való társulását a szakirodalom a céhes keretek között a polgári mentalitás egy korai próbálkozásaként írja le, miközben vélhetően nem volt másról szó, mint a Pollack fiú céhes mesterjoga mögé való beállásról. Yblnek azonban néhány év alatt más fordulatot vett a pályája, és a pesti, polgári építkezések helyett a Károlyi család uradalmába került mint építész, ahol jóval nagyobb alkotói szabadsága lehetett bizonyos kérdésekben. Pollack Ágostont pedig talán jobban vonzotta az éppen szétválófélben lévő építőmesteri hivatás ${ }^{149}$ másik része, a jövedelmezőbb kivitelezés. A tanulmányban tárgyaltak alapján a két fiatal építész társulását inkább laza szövetségként képzelhetjük el, ahol egymás segítése és néhány közös munka mellett, mindketten önálló utakon is jártak. A Pollack Ágoston által szignált, fennmaradt pesti engedélyezési tervek között nem található olyan munka, amely mögött stíluskritikai alapon Ybl szerzősége is felmerülhetne. Az azonban tagadhatatlan, hogy ebben az időszakban készült munkáiban a stílusbeli újításra való hajlam is benne volt - talán Ybl hatására. Nagy valószínűséggel kettejük társulására is igaz az a sokszor látott gyakorlat, hogy míg az egyik építész az épületek mủvészi koncepciójáért felelt, a másik inkább a gyakorlatiasabb, mérnöki teendőket felügyelte.

Pollack Ágoston tevékenységének negatív értékelése az apa és a pályatárs sokkal nagyobb jelentőségével magyarázható. Ahogyan Zádor Anna is írta ,,[h]a nem lett volna atyja fia: talán jobban elhelyezhetnők a középszerü tehetségek sorában". ${ }^{150}$ És valóban, a Pollack fiúnak biztos helye van a 19. század közepének pesti építészeinek és építőmestereinek névsorában. Abban a névsorban, melyből édesapja és egykori cég- és munkatársa kiemelkedik. Ybl Miklós pályája derekán is jó szívvel és hálával emlékezett vissza fiatalkori mesterére, Pollack Mihályra: „Pollák (...) kitünö épitész volt, alapos ismeröje a régi formáknak, müködésében mindig tiszta, klasszikai alakok körében mozgott, s a mit nála láttam és töle tanultam: az megmaradt nekem egész életemre!"151

${ }^{149}$ Voit 1960. 269.

${ }^{150}$ Zádor-Rados 1943. 91.

${ }^{151}$ Ybl Miklóst az őt személyesen is jól ismerő Neÿ Béla idézi. (Neÿ 1879. 811.) Az 1891-ben Pollack Mihályról író, személyesen Ybltől informálódó $H$. Gaál Adorján és a századfordulón szintén a klasszicista mesterről író Sándy Gyula (1868-1953) is fontosnak tartotta Yblnek egykori mesteréről mondott szavait ismertetni, ezeken a helyeken azonban némileg másképp szólt az idézet: „Szigorú, egyenes jellemü, nagy tudású ember volt s én mindig örömmel emlékszem vissza a nála töltött idöre. Ö szives barátsággal viszonozta hozzá való ragaszkodásomat, s amit töle tanultam, az megmaradt nekem egész életemre. (H. Gaál 1891. 3 és Sándy 1907. 6.) 


\section{IRODALOM}

Bachó 1930

Balogh 1958

Balogh 1998

Bibó 1973

Bibó 1977

Bibó 1984

Bibó 2008

Bierbauer 1932

Bugár 2005

Debreczeni 2014

Déry 2005

Déry 2006

Duray 1914

Éble 1897

Farbaky 2001

Farbaky 2003

Fleischer 1935

G. Szabó 1988

Gábor 2004
Dezséri Bachó László: A pesti Ludoviceum története 1830-tól 1848-ig. In: A Magyar Kir. Honvéd Ludovika Akadémia Története. Szerk.: Dezséri Bachó László. M. Kir. H. Ludovika Akadémia, Budapest 1930.

Balogh István: Debrecen. (Magyar Mủemlékek) Képzőmúvészeti Alap Kiadóvállalata, Budapest 1958.

Gy. Balogh Ágnes: Adatok a budai kőműves és kőfaragó céh életéből (1690-1872). Épités- Épitészettudomány 27 (1998) 1-2. 93-123.

Bibó István: Pollack Mihály Országháza-terve. Müvészettörténeti Értesitö 22 (1973) 1. 22-36.

Bibó István: A pesti Szerb utcai volt klarissza kolostor építéstörténete. Épités- Épitészettudomány 9 (1977) 2-3. 175-228.

Bibó István: Az egykori Károlyi-palota építésének története. ÉpitésÉpitészettudomány 16 (1984) 1-2. 195-248.

Bibó István: Pollack Mihály. (Az építészet mesterei) Holnap Kiadó, Budapest 2008.

Bierbauer Virgil: Pesti építőmesterek munkássága 1809-1847. In: Tanulmányok Budapest Multjából. Budapest Székesfőváros, Budapest 1932. 76-98.

Bugár-Mészáros Károly: Bukovics Gyula és Kossuth téri minisztériumi épülete. In: Budapest neoreneszánsz épitészete - Tanulmányok. Szerk.: Csáki Tamás, Hidvégi Violetta, Ritoók Pál. Budapest Főváros Levéltára, Budapest 2009. 189-204.

Debreczeni-Droppán Béla: Ybl Miklós és a Magyar Nemzeti Múzeum. In: Ybl-épületsorsok az Unger-háztól a Kálvin térig. Szerk.: Hidvégi Violetta - Marótzy Katalin. Budapest Főváros Levéltára, Budapest 2014. 27-45.

Déry Attila: Belváros-Lipótváros. (Budapest építészeti topográfia 2.) TERC Kiadó, Budapest 2005.

Déry Attila: Terézváros-Erzsébetváros. (Budapest építészeti topográfia 3.) TERC Kiadó, Budapest 2006.

Duray Kálmán: A budai és pesti kőmüves, kőfaragó és ács céhek. In: Budapesti épitö mesterek, kömüves-, köfaragó- és ács mesterek ipartestülete X. évkönyve. Budapest 1914. 69-155.

Éble Gábor: A Károlyi grófok nagykárolyi várkastélya és pesti palotája. Hornyánszky Viktor Könyvnyomdája, Budapest 1897.

Farbaky Péter: A budai királyi palota a historizmus korában - Ybl Miklós és Hauszmann Alajos átépítési terveinek fejlődése és kapcsolata. In: Tanulmányok Budapest Múltjából 29. Budapest 2001. 241-263.

Farbaky Péter: A Sándor-palota, a Teleki-palota és az udvari istálló: a Szent György tér épületeinek változásai az újkorban. In: Tanulmányok Budapest Múltjából 31. Budapesti Történeti Múzeum, Budapest 2003. 137-160.

Fleischer Gyula: Magyarok a bécsi képzömüvészeti Akadémián. [k. n.], [h. n.] 1935.

G. Szabó Botond: A kollégium épületeinek története. In: A Debreceni Református Kollégium története. Föszerk.: Kocsis Elemér. Egyetemi Nyomda, Budapest 1988. 351-392.

Gábor Eszter: Tornyos villák a Városligeti fasorban. In: Romantikus kastély - Tanulmányok Komárik Dénes tiszteletére. Hild-Ybl Alapítvány, Budapest 2004. 209-216. 
Gábor 2010

Gerle 2010

H. Gaál 1891

Hidvégi 2014

Horváth 1928

Jász 2015

Kalmár 1999

Kelecsényi-Torma 2015

Komárik 1971

Komárik 1993

Krähling 2009

Kun 1930

Lyka 1933

Marótzy 2014

Neÿ 1879

Neÿ 1907

Pereházy 1982

Prokopp 1981

Prokopp 1994

Réh 1933

Ritoók 2007
Gábor Eszter: Az Andrássy út körül. Osiris - Budapest Főváros Levéltára, Budapest 2010.

Gerle János: Korb Flóris - Giergl Kálmán. (Az építészet mesterei) Holnap Kiadó, Budapest 2010.

H. Gaál Adorján: Polláck Mihály (1773-1885). Építő Ipar - Müszaki Hetilap 15 (1891) 1. 1-3.

Hidvégi Violetta: Unger Henrik bérháza, 1852-1853. In: Ybl-épületsorsok az Unger-háztól a Kálvin térig. Szerk.: Hidvégi Violetta, Marótzy Katalin. Budapest Főváros Levéltára, Budapest 2014. 46-53.

Horváth Károly: Hetven év a Ludovica Akadémia alapítási történetéből (1802-1872). Historia 1928. 42-45.

Jász Borbála: Linzbauer István (1838-1880) Császári és királyi építész életmüve. In: Épitömüvészek Ybl és Lechner korában. Szerk.: Rozsnyai József. TERC Kiadó, Budapest 2015. 38-63.

Kalmár Miklós: Pollack Mihály. Architectura Hungariae 1 (1999) 3. http:// arch.et.bme.hu/arch_old/epitesz3.html\#3 (Utolsó megtekintés: 2016. 01. 16.)

Kelecsényi Kristóf - Torma Ágnes: Schmahl Henrik (1846-1912) - Egy német kőmüveslegény felemelkedése a dualizmus kori Budapesten. In: Épitömüvészek - Ybl és Lechner korában. Szerk.: Rozsnyai József. TERC Kiadó, Budapest 2015. 92-133.

Komárik Dénes: Építészképzés és mesterfelvétel a XIX. században. Pesti mesterek és mesterjelöltek. Épités- Épitészettudomány 3 (1971) 4. 379418.

Komárik Dénes: Feszl Frigyes (1821-1884). Akadémiai Kiadó, Budapest 1993.

Krähling, János: La chiesa evangelica di Pest di Mihály Pollack. In: Leopoldo Pollack e la sua famiglia: Cantiere, formazione e professione tra Austria, Italia e Ungheria. Szerk.: Giuliana Ricci, Giovanna D'Amia. Istituto per la Storia dell'Arte Lombarda, Milánó 2009. 187-194.

Kun Ágota, Szentpéteri: A debreceni református nagytemplom (18051827). Városi Nyomda, Debrecen 1930.

Lyka Károly: Adatok építészetünk történetéhez. Magyar Müvészet 9 (1933) 2. 56-59.

Marótzy Katalin: Dlauch Károly bérháza, 1862-1863. In: Ybl-épületsorsok az Unger-háztól a Kálvin térig. Szerk.: Hidvégi Violetta - Marótzy Katalin. Budapest Főváros Levéltára, Budapest 2014. 46-53.

Neÿ Béla: Ybl Miklós. Vasárnapi Ujság 26 (1879) 51. 811-812.

Neÿ Béla: [cím nélkül]. Magyar Épitömüvészet 5 (1907) 7. 6.

Pereházy Károly: Egy jelentős pesti vasműves család. Épités- Épitészettudomány 14 (1982) 1-2. 229-246.

Prokopp Gyula: Prokopp János. Épités- Épitészettudomány 13 (1981) 1-2. 137-159.

Prokopp Mária, dr.: Prokopp János 1825-1894 - Esztergom megye és város elsö mérnöke. (Emlékkiállítás a Balassa Bálint Múzeumban) Esztergom 1994.

Révhelyi (Réh) Elemér, Dr.: Az Egyetem-utcai volt Károlyi-palota építésének története. In: Tanulmányok Budapest Multjából 2. Budapest Székesfőváros, Budapest 1933. 87-103.

Ritoók Pál: Adalékok a fóti kastély építéstörténetéhez. In: A fóti templom és a romantika épitészete. TERC Kiadó, Budapest 2007. 202-208. 
Sándy 1907

Schneider 1910

Schneider 1912

Schoen 1938

Schoen 1939

Sisa 1994

Sisa 2007

Sisa 2013

Sisa 2014

Vadas 2007

Voit 1960

Ybl 1956a

Ybl 1956b

Ybl 1991

Ybl 2002

Zádor 1931

Zádor 1952

Zádor 1960

Zádor 1963

Zádor-Rados 1943

Zoltai 1929
Sándy Gyula: Pollák Mihály élete és müvei. Magyar Épitómüvészet 5 (1907) 12. 2-6.

Schneider Róbert: „Régi czéhtagok». In: Budapesti Épitő Mesterek, Kömíves-, Köfaragó és Ács Mesterek Ipartestülete VI. évkönyve. Budapest 1910. 188-190.

Schneider Róbert: A pesti kőmives- és kőfaragó czéh tagjai. A régi mesterkönyvek szerint. In: Budapesti Épitö Mesterek, Kömíves-, Köfaragó és Ács Mesterek Ipartestülete VIII. évkönyve. Budapest 1912. 211-217.

Schoen Arnold: A pesti Szent Rókus kápolna. Budapest 1938.

Schoen Arnold: Budapest székesfőváros kórházainak és emberbaráti intézményeinek kápolnái. In: Tanulmányok Budapest Múltjából 7. Budapest 1939. 11-40.

Sisa József: Szkalnitzky Antal - Egy épitész a kiegyezés korabeli Magyarországon. Akadémiai Kiadó, Budapest 1994.

Sisa József: Kastélyépitészet és kastélykultúra Magyarországon - A historizmus kora. Vince Kiadó, Budapest 2007.

A magyar müvészet a 19. században - Épitészet és iparmüvészet. Szerk.: Sisa József. (A magyarországi mủvészet története. Sorozatszerk.: Beke László, Sisa József.) MTA Bölcsészettudományi Kutatóközpont - Osiris Kiadó, Budapest 2013.

Sisa József: Ybl Miklós, a kastélyépítész. Ars Hungarica 40 (2014) 4. 549-559.

Vadas Ferenc: Pesti gázgyártervek az 1850-es évekböl. In: A fóti templom és a romantika épitészete. Szerk.: Buda Attila, Ritoók Pál. Budapest 2007. Voit Pál: Tervek, mesterek és a mü. Müvészettörténeti Értesitö 9 (1960) 4. 265-279.

Ybl Ervin: Ybl Miklós. Képzőművészeti Alap, Budapest 1956.

Ybl Ervin: A budai várpalota helyreállítása a XIX. század derekén. In: Tanulmányok Budapest Múltjából 11. Budapest 1956. 307-333.

Ybl Miklós épitész - 1814-1891. A Hild-Ybl Alapítvány kiállítása a Budapesti Történeti Múzeumben 1991. december - 1992. március. (Szerk.: Kemény Mária, Farbaky Péter.) Hild-Ybl Alapítvány, Budapest 1991.

Ybl Miklós. (Az építészet mesterei) Szerk.: Gerle János - Marótzy Kata. Holnap Kiadó, Budapest 2002.

Zádor Anna: Leopoldo Pollack és Pollák Mihály. (Különlenyomat az Archaelogiai Értesítő 1931. évi XLV. kötetéből.) Franklin Nyomda, Budapest 1931.

Zádor Anna: A magyar klasszicizmus épitömesterei. Tankönyvkiadó Jegyzetsokszorosító Üzeme, Budapest 1952.

Zádor Anna: Pollack Mihály 1773-1855. Akadémiai Kiadó, Budapest 1960.

Zádor Anna: A magyarországi palladianizmus: a két Pollack. Épités- és Közlekedéstudományi Közlemények 7 (1963) 3. 227-252.

Zádor Anna - Rados Jenő: A klasszicizmus épitészete Magyarországon. Magyar Tudományos Akadémia, Budapest 1943.

Zoltai Lajos: A debreceni Kistemplom története. Debreceni Képes Kalendárium 30 (1929), Debrecen 1929. 


\title{
MIKLÓS YBL AND THE POLLACK FAMILY
}

\begin{abstract}
Summary
Miklós Ybl (1814-1891) belonged to those generations of early $19^{\text {th }}$ century born architects whom had to gain the right of designing and constructing in the midst of still existing, but declining guilds and their traditions. In the forming of Ybl's career his master, Mihály Pollack (1773-1855) and the Viennese Heinrich Koch (1781-1861) had a definite rule. Until he became full member of the guild, the young Ybl collaborated with Ágoston Pollack (1812-1872), Mihály's son, who had the warrant from the guild, and tried to establish a practice. The most significant building of the almost decade-long partnership is the Batthyány-mansion in Ikervár. This is the time also when Ybl's relationship to the Károlyi family started. Their orders in Fót, and on account of those, the gained position of manorial architect provided wealthy subsistence and also the opportunity of being known in the circles of aristocracy. The partnership with the younger Pollack ended at latest around 1850. The son of Mihály Pollack slowly turned from designing small and mid-sized houses to constructions and in the middle of the 1860's he laid off architecture for good. However, the connection between Miklós Ybl and the Pollack family have not ended, he designed Mihály's grave, and adopted his orphaned grandchild.
\end{abstract}

Keywords: Mihály Pollack, Ágoston Pollack, Miklós Ybl, master and apprentice, neoclassicism, romanticism, historicism 